IZA DP No. 4376

Child Labor and Trade Liberalization in Indonesia

Krisztina Kis-Katos

Robert Sparrow

August 2009 


\title{
Child Labor and Trade Liberalization in Indonesia
}

\author{
Krisztina Kis-Katos \\ University of Freiburg \\ Robert Sparrow \\ Erasmus University Rotterdam \\ and IZA
}
Discussion Paper No. 4376
August 2009

\author{
IZA \\ P.O. Box 7240 \\ 53072 Bonn \\ Germany \\ Phone: +49-228-3894-0 \\ Fax: +49-228-3894-180 \\ E-mail: iza@iza.org
}

\begin{abstract}
Any opinions expressed here are those of the author(s) and not those of IZA. Research published in this series may include views on policy, but the institute itself takes no institutional policy positions.

The Institute for the Study of Labor (IZA) in Bonn is a local and virtual international research center and a place of communication between science, politics and business. IZA is an independent nonprofit organization supported by Deutsche Post Foundation. The center is associated with the University of Bonn and offers a stimulating research environment through its international network, workshops and conferences, data service, project support, research visits and doctoral program. IZA engages in (i) original and internationally competitive research in all fields of labor economics, (ii) development of policy concepts, and (iii) dissemination of research results and concepts to the interested public.
\end{abstract}

IZA Discussion Papers often represent preliminary work and are circulated to encourage discussion. Citation of such a paper should account for its provisional character. A revised version may be available directly from the author. 
IZA Discussion Paper No. 4376

August 2009

\section{ABSTRACT \\ Child Labor and Trade Liberalization in Indonesia ${ }^{*}$}

We examine the effects of trade liberalization on child work in Indonesia. Our estimation strategy identifies geographical differences in the effects of trade policy through district level exposure to reduction in import tariff barriers. We use a balanced panel of 261 districts, based on four rounds (1993 to 2002) of the Indonesian annual national household survey (Susenas), and relate workforce participation of children aged 10-15 to geographic variation in relative tariff exposure. Our main findings show that increased exposure to trade liberalization is associated with a decrease in child work among the 10 to 15 year olds. The effects of tariff reductions are strongest for children from low skill backgrounds and in rural areas. Favorable income effects for the poor, induced by trade liberalization, are likely to be the dominating effects underlying these results.

JEL Classification: J13, O24, O15

Keywords: $\quad$ child labor, trade liberalization, poverty, Indonesia

Corresponding author:

Robert Sparrow

Institute of Social Studies

Erasmus University Rotterdam

P.O. Box 29776

2502 LT The Hague

The Netherlands

E-mail: sparrow@iss.nl

\footnotetext{
* We thank Arjun Bedi, Sebi Buhai, Eric Edmonds, Pedro Goulart, Michael Grimm, Umbu Reku Raya, Günther Schulze and Bambang Sjahrir Putra for useful comments and discussions, as well as seminar and conference participants at Aarhus School of Business, Freiburg University, Institute of Social Studies, the Second IZA Workshop on Child Labor in Developing Countries, and the Fourth Annual Conference of the German Research Committee on Development Economics. All errors are our own.
} 


\section{Introduction}

The effects of trade liberalization on child labor are widely debated and public and political interest in the issue is high. From a theoretical perspective these effects are a priori unclear (e.g., Ranjan 2001, Jafarey and Lahiri 2002) as trade liberalization acts potentially through several channels, changing relative prices, real income distribution, wages and net returns to education. The arising income and substitution effects can both raise and reduce workforce participation of children.

Empirical evidence on the issue is scarce. Cross-country studies generally find trade liberalization to be associated with lower incidence of child labor on average (Cigno, Rosati and Guarcello 2002), a relationship that seems most likely to be driven by the effect of trade on income, as more open economies have less child labor because they are richer (Edmonds and Pavcnik 2006). Kis-Katos (2007) finds differential effects of trade openness, with smaller reductions in child labor for the poorest food exporting countries. However, empirical studies based on micro data and direct evidence from trade reforms are required to understand the heterogenous effects from trade liberalization and identify the main channels at work. For example, Edmonds and Pavcnik (2005b) find that rice price increases due to a dismantling of export quotas in Vietnam led to an overall decrease in child labor in the 1990s, especially due to the relatively evenly distributed favorable income effects. In contrast, Edmonds, Pavcnik and Topalova (2007) find that in rural India, districts that have been more strongly exposed to trade liberalization have experienced smaller increases in school enrollment on average, which they argue is primarily due to the unfavorable income effects to the poor and the relatively high costs of education in these districts.

This study contributes to the empirical micro literature by examining the trade 
liberalization experience of Indonesia in the 1990s, which, given the vast geographic heterogeneity of the archipelago, offers an interesting case study on the effects of trade liberalization on child work. In preparation to and following its accession to the WTO, Indonesia went through a major reduction in tariff barriers: average import tariff lines decreased from around 19.4 percent in 1993 to 8.8 percent in 2002. During that same period the workforce participation of children aged 10 to 15 years more than halved. Due to Indonesia's size and geographic variation in economic structure, the various districts have been very differently affected by trade liberalization, which offers us a valuable identification strategy.

Our identification strategy follows that of Topalova (2005) and Edmonds et al. (2007), as we combine geographic variation in sector composition of the economy and temporal variation in tariff lines by product category, yielding geographic variation in (changes in) average exposure to trade liberalization over time. We extend this approach in several ways. First, we define two alternative measures of geographic exposure to trade liberalization, by weighting tariffs on different products by the shares these sectors take in (i) regional GDP, and (ii) the regional structure of employment. These measures reflect different dimensions of households' exposure to trade liberalization: the former through the distributional effects of local economic growth, the latter through labor market dynamics. In addition to this, the data allows us to go beyond the fixed effects approach employed in earlier studies and investigate the dynamic effects of trade liberalization.

The analysis draws on a variety of data sources. Indonesia's annual national household survey (Susenas) provides information on the main activities of children and their basic socio-economic characteristics. We use four rounds of this repeated cross section data, spaced at 3-year intervals between 1993 and 2002. As the Susenas is representative at the district level, we apply our analysis both 
at the individual level using pooled repeated cross section data with district fixed effects, and at the district level with pseudo panel data for 261 districts. The data on economic structure of the districts comes from information on regional GDP (GRDP) of the Central Bureau of Statistics in Indonesia (BPS), while district-

level employment shares and further controls are based on Susenas. Additional district-level information is derived from PODES, the Village Potential Census. Finally, information on tariff lines comes from the UNCTAD-TRAINS database.

We find that stronger exposure to trade liberalization has lead to a decrease in child labor among the 10 to 15 year olds. The effects are strongest for children from low skill backgrounds and in rural areas. Favorable income effects for the poor induced by trade liberalization are likely to be the dominating effects underlying these results.

The next section of the paper provides a theoretical framework for our analysis. The third section elaborates on the context of the tariff reductions in Indonesia, and the developments in child labor for our study period. Section 4 presents the data and sets out the identification strategy. The results are then discussed in section 5 while section 6 concludes.

\section{Theoretical background}

Although child labor is determined by an interaction between the necessity and the opportunities to work, credit constraints, returns to school, as well as parental preferences, its close link to poverty is undisputed (Edmonds and Pavcnik 2005a). Hence, reductions in trade barriers are more likely to lead to reductions in child labor if they are going to benefit the poor in the economy. Based on standard Stolper-Samuelson reasoning, trade liberalization has been commonly expected 
to alleviate poverty in developing countries (e.g., Bhagwati and Srinivasan 2002). However, if specialization in production also increases the demand for unskilled labor, the overall effects on child labor are a priori not clear.

Even in its simplest version, the Stolper-Samuelson reasoning does not necessarily imply a reduction in child labor due to trade liberalization, as the resulting income and substitution effects point into different directions. In a HeckscherOhlin economy with two mobile factors, low and high skilled labor, and two industries producing one export and one import-competing good, reducing import tariffs leads to a decrease in the relative price of the imported good with respect to the numéraire (export good). On the production side, there will be a shift towards the production of exportables with low skill intensity, which in turn raises the demand for unskilled labor and reduces the skill premium in the economy 1 The price changes will also lead to consumption shifts, and the overall effects of trade liberalization are expected to be positive (gains from trade). Households will be affected by changing goods and factor prices through two main channels. First, changes in wages and goods prices alter the real income of the households. Second, shifts in the relative prices of goods and opportunity costs of not working result in substitution effects which lead to a further reallocation of consumption and labor supply. While real incomes of the poor low-skilled households should increase after trade liberalization, the overall reaction of child labor is not clear-cut, since rising real wages of the unskilled increase the incentives to work.

More formally, consider a household consisting of one child and one adult where the adult chooses consumption of two goods $\left(c_{1}, c_{2}\right)$, and allocates the child's time

\footnotetext{
${ }^{1}$ These price effects might be both mitigated and enhanced in the presence of non-tradable goods: If the import-competing sector is more capital intensive than both the exporting and the non-traded sectors (as it might be expected in a developing economy), the relative price of the non-traded good with respect to the numéraire (exportable) will rise. Overall demand and production shifts will in this case depend on the relative factor intensities of each industry and the gross substitutability of all goods in consumption (Komiya 1967).
} 
between work $(l)$, and schooling $(1-l)$ in order to maximize household utility. The utility of schooling $(\nu(1-l))$ reflects both disutility of child labor and the discounted present value of the returns to school. The decision is made subject to the household's budget constraint and the time constraints for the child, assuming that financial markets are typically imperfect such that the household cannot borrow against the child's future income in order to invest into education, even if the discounted net returns to education would be positive 2 The budget constraint states that the expenditures on consumption goods and schooling $(\sigma(1-l))^{3}$ cannot be higher than the adult's income $(y)$ plus the income from child labor $(\gamma w l) \underline{4}$

$$
\max _{c_{1}, c_{2}, l} u\left(c_{1}, c_{2}\right)+\nu(1-l) \quad \text { s.t. } \quad y+\gamma w l=p c_{1}+c_{2}+\sigma(1-l), 0 \leq l \leq 1
$$

The relative price of the importables $\left(c_{1}\right)$ is denoted by $p$, unskilled wages by $w$. The child is assumed to be a perfect although less productive $(\gamma<1)$ substitute for unskilled adult labor (substitution axiom by Basu and Van 1998). Given the optimal allocation of income over the two consumption goods, optimal (uncompensated) child labor supply $\left(l^{*}\right)$ is determined by relative goods and factor prices, school costs and adult income:

$$
l^{*}=l(p, w \gamma, \sigma, y)
$$

For an interior solution (where the child combines work and schooling), the opti-

\footnotetext{
${ }^{2}$ Credit constraints and imperfect smoothing seem a reasonable assumption for most developing countries, at least for those households that send their children to work, as credit constraints are among the main causes for child labor (e.g., Beegle, Dehejia and Gatti 2006). For Indonesia Kis-Katos and Schulze (2009) show that credit availability is closely related to the incidence of child labor in small businesses.

${ }^{3}$ The direct costs of schooling (excluding opportunity costs) are denoted by $\sigma$, and for simplicity, are assumed to be linear in school time.

${ }^{4}$ If the adult is unskilled, adult income equals the unskilled wage $y=w$, if the adult is skilled, adult income equals the skilled wage. In both cases adult labor is assumed to be inelastic in supply.
} 
mality condition is given by:

$$
w \gamma v_{y}(p, w \gamma, \sigma, y)=\nu^{\prime}(1-l)-\sigma v_{y}(p, w \gamma, \sigma, y)
$$

which is expressed in terms of an indirect utility function $(v(p, w \gamma, \sigma, y))$. The work-school trade-off depends thus on the relative magnitudes of the real value of the marginal product of child labor (left hand side of equation (2) ) and the net real marginal returns to education (right hand side of equation (2)), with marginal utility of income $\left(v_{y}\right)$ denoting the inverse of the price deflator. A child will be doing at least some work, if real child wages are greater than the marginal real net return to education if the child spends all its available time on learning $(l=0) 5$

After reducing import tariffs, imported and import competing products become relatively less expensive $(d p<0)$, the overall effect of which can be seen by totally differentiating the uncompensated child labor supply equation (10):

$$
d l^{*}=(\underbrace{\frac{\partial l}{\partial p}}_{-?}+\gamma \underbrace{\frac{\partial l}{\partial w}}_{+?} \underbrace{\frac{\partial w}{\partial p}}_{-}+\underbrace{\frac{\partial l}{\partial y}}_{-} \underbrace{\frac{\partial y}{\partial p}}_{-?}) d p
$$

The first term within the parentheses captures the direct effects of a price increase and is negative if schooling and the import competing good are gross substitutes: As schooling becomes relatively less expensive, child labor will decrease but the substitution effect is (partly) counteracted by a decrease in real income due to the price increase. The first part of the second term captures both the income and substitution effects from an increase in child wages: if the substitution effect dominates, rising wages increase child labor supply 6 The second part of

\footnotetext{
${ }^{5}$ Conversely, a child will be spending at least some time going to school if real child wages are smaller than the marginal net returns to education at no schooling $(l=1)$. For expositional ease we abstract from the possibility that a child stays idle, which will be most likely if both real net returns to education and value of marginal product of child work are low.

6 Additionally, there might be dynamic effects of falling skill premia, which make investment into education less profitable, reduce $\nu^{\prime}(1-l)$ and thus raise $\partial l / \partial w$ further. But as technological
} 
the term captures the change in unskilled wages with an increase in import prices and is negative by a Stolper-Samuelson argument. The third term captures the effect through adult income: if the adult has unskilled labor, an increase in the import price should decrease adult income, and hence increase child labor. The overall sign of these effects depends on whether the favorable income effects or the substitution effects are dominating 7 Departures from the Stolper-Samuelson reasoning that result additionally in negative income effects for the poor make an increase in child labor more likely.

The expected favorable effects of trade liberalization on child labor depend strongly on the presence of Stolper-Samuelson linkages which has been widely questioned over the last decades, both on theoretical and empirical grounds. Theoretically, the Stolper-Samuelson conclusions fail to hold for many real-world relevant departures from the simplest framework (e.g., Davis and Mishra 2007). Splitting "the rest of the world" into multiple trading partners reveals that a developing country might trade both with more and less skill-abundant countries than itself, in which case reductions in tariffs on goods with low-skill intensity might also hurt the poor. The poor will suffer also if the effects of trade liberalization are accompanied and even dominated by skill biased technological change. In contrast, reductions in tariffs on goods that are not produced within a country will have no effects on protection and will only benefit consumers of those goods.

Favorable income effects are more likely to occur if intersectoral worker mobility is high and markets are competitive, which corresponds to a longer run

upgrading is certainly an issue in the long run, this gives an additional motive for human capital accumulation and makes the longer term relevance of short term falls in skill premia questionable.

7 Although the above arguments have been presented on the intensive margin (with both work and school being interior), the effects translate easily to the extensive margin as well: The workforce participation of a child is influenced through the same channels as presented above, and the share of children working and/or enrolled at school is influenced by changes in district poverty and wages/labor market conditions, and hence by the same income and substitution effects. 
perspective. If workers' skills are industry specific instead and hence the between industry mobility is low, workers might be harmed in the short run by reductions in protection. In a constrained economic environment, with imperfect smoothing, such short term economic shocks can also have long term consequences for the poor. For instance, decisions on withdrawing a child from school in face of a shock are often irreversible and can have intergenerational effects.

Empirical evidence on the effects of globalization on poverty is also inconclusive, since, contrary to the Stolper-Samuelson predictions, many empirical studies do not observe reductions either in poverty or in wage inequality in developing countries that reduced tariffs unilaterally (e.g., Harrison 2007).8 For Indonesia, however, the pro-poor effects of trade liberalization are not unlikely: Suryahadi (2001) documents rising unskilled wages over the period of trade liberalization in the 1990s, while Sitalaksmi, Ismalina, Fitrady and Robertson (2007) find improvements in perceived working conditions. Indeed, our results seem to suggest that tariff reductions have induced income effects and reduced poverty, eventually leading to a reduction in rural child labor.

Our empirical analysis will focus on child labor and not on schooling, since consistent data on school attendance is not available for the study period (see also the data section). In addition, we will not consider the effects of trade liberalization propagated through changes in consumption patterns, but only analyze the channels associated with the composition of economic activity 9

\footnotetext{
${ }^{8}$ Reductions in protection are more likely to benefit the poor if labor mobility between industries is high and labor market policies are flexible, and if social safety nets are well-functioning (Harrison 2007).

${ }^{9}$ For our empirical strategy this implicitly implies that differences in district-level trends in the composition of consumption are assumed to be unrelated to the districts' economic production structure; in which case not controlling for the consumption channel will not confound our estimates.
} 


\section{Trade liberalization and children in Indonesia}

\subsection{Trade liberalization in the 1990s}

Trade liberalization in Indonesia took place over more than fifteen years. From the mid-1980s the former import substitution policy has been gradually replaced by a less restrictive trade regime, tariff lines have been reduced while at the same time a slow tarification of non-tariff barriers took place (Basri and Hill 2004). This laid the ground to the next wave of trade liberalization in the mid-1990s, with rising foreign firm ownership and increasing export and import penetration 10 Tariff reductions were particularly strong in the 1990s, with Indonesian trade liberalization policy in that decade being defined by two major events: the conclusion of the Uruguay round in 1994 and Indonesia's commitment to multilateral agreements on tariff reductions, and the Asian economic crisis in 1997 and the post-crisis recovery process. After the Uruguay round Indonesia committed itself to reduce all of its bound tariffs to less than 40\% within ten years. In May 1995 a large package of tariff reductions was announced which laid down the schedule of major tariff reductions until 2003, and implemented further commitments of Indonesia to the Asia Pacific Economic Cooperation (Fane 1999). While the removal of specific non-tariff barriers was accompanied by a temporary rise in tariffs (especially in the food manufacturing sector), this did not affect the overall declining trend in any major way.

Figure 1 shows the reduction in tariff lines over time and the variation between industries. On average, nominal tariffs reduced from 17.2 percent in 1993 to 6.6 percent in 2002. In this period the strongest reductions occurred from 1993 to

\footnotetext{
${ }_{10}$ Arguably, cronyism and specific protection of a few industries with ties to the Soehartofamily - especially chemicals, motor vehicles and steel — reduced the effect of overall liberalization. However, the largest part of the cronyism occurred in nontraded sectors and did not further affect protection of the traded sectors (Basri and Hill 2004, p.637).
} 
1995 and during the post crisis period after 1999. Tariff dispersion decreased especially in the post-crisis period when reductions were more universal. While tariffs decreased across the board, there were marked differences in initial levels and in the extent of the decrease (see Figure 2). Manufacturing started with relatively high tariff barriers but also showed the strongest reductions. For example, wood and furniture saw tariffs decline from 27.2 to 7.9 percent, textiles form 24.9 to 8.1 percent and other manufacturing from 18.9 to 6.4 percent. The average tariffs for agriculture were already much lower in 1993, at 11.5, and which reduced to 3.0 percent 11

Existing studies on the effects of Indonesian trade liberalization document both increased firm productivity and improvements of working conditions in manufacturing. At the plant-level, Amiti and Konings (2007) find that trade liberalization affected firms' productivity through two main channels: falling tariffs on imported inputs fostered learning and raised both product quality and variety, while falling output protection increased the competitive pressures. Comparing the two effects they argue that gains from falling input tariffs were considerably higher. Firm productivity has also been strongly affected by FDI flows, as firms with increasing foreign ownership experienced restructuring, employment and wage growth, as well as stronger linkages to export and import markets (Arnold and Smarzynska Javorcik 2005). At the same time, working conditions seem to have improved, especially in manufacturing. Using individual employment data, Sitalaksmi et al. (2007) argue that the increase in export-oriented foreign direct investment went along with rising relative wages in the textile and apparel sector. Additionally, working conditions, proxied by workers' own assessment of their income, working facilities, medical benefits, safety considerations and transport opportunities,

\footnotetext{
${ }^{11}$ Figure 3 shows that tariff reductions and tariff levels are reasonably positively related; all outliers showing significant increases in tariffs are related to alcoholic beverages and soft drinks that were subject to a major retarification of non-tariff barriers.
} 
improved over time in the expanding manufacturing industries as compared to agriculture.

Based on a microsimulation exercise Hertel, Ivanic, Preckel and Cranfield (2004) argue that full multilateral trade liberalization is expected to decrease household poverty in Indonesia, although self-employed agricultural households would be the most likely losers of trade liberalization in the short-run, which is mainly due to the assumption that self-employed labor is immobile in the shortrun. In the longer run some former agricultural workers will be moving into the formal wage labor market and the poverty headcount could be expected to fall for all sectors. However, the mobility of low skill labor, and hence the speed and ability to exploit the opportunities from trade liberalization, may be underestimated by Hertel et al. (2004). For example, Suryahadi, Suryadarma and Sumarto (2009) show that during the 1990s the agriculture employment share dropped from 50 to 40 percent, while the services share increased from 33 to 42 percent. In addition, they attribute most of the poverty reductions in that decade to growth in urban services. This is further supported by Suryahadi (2001), who documents a fast increase in the employment of skilled labor force as well as a decline in wage inequality (i.e. faster wage growth for the unskilled) during trade liberalization in Indonesia, although he does not establish causality.

\subsection{Child work}

Indonesia experienced a steady decline in child work in the thirty years before the Indonesian economic crisis, but this decline halted with the onset of the crisis (e.g., Suryahadi, Priyambada and Sumarto 2005). Nevertheless, market work among children aged 10 to 15 increased only slightly in response to the economic crisis 
(e.g., Cameron 2001) 12 During the crisis children have been moving out of the formal wage employment sector into other small-scaled activities (Manning 2000), but the labor supply response seems to be concentrated with older cohorts.

The overall decline in child work over the study period is portrayed in Figure 4. for boys and girls, and by different age groups. Child work is here defined as any work activity that contributes to household income. From 1993 to 2002, the incidence of child work halves for children of junior secondary school age (13 to 15 years old), and is cut by more than 70 percent for children age 10 to 12 . This decline is observed for both boys and girls, although boys engage in market work more than girls. In 2002 market work incidence for boys age 13 to 15 years is 14.8 percent, and 2.3 percent for boys at age 10 to 12 . Among girls market work incidence is 10.0 and 1.6 percent for the same age groups, respectively.

Agriculture is the main sector for child work, and developments in this sector are driving the overall trends, as shown in Figure 5. In 1993 just over 75 percent of child work in the age group 10 to 12 occurred in agriculture, while two in three child workers aged 13 to 15 worked in agriculture. The dominance of the agricultural sector in child work translates into a 79 and 69 percent share in the overall reduction in child work for the two age groups, respectively. However, the relative changes from 1993 to 2002 are remarkably constant across sectors.

The trends in child work vary greatly by location and education attainment of the head of household (Table 1). Child work incidence is much higher in rural districts compared to municipalities, but rural areas experienced the largest decline, both in absolute and relative terms. These patterns mirror the trend dominance of the agricultural sector. Child work incidence decreases with the level of education of the head of household. Boys living in households where the head of household

\footnotetext{
12 Information on working children below the age of 10 is not available at a systematic basis.
} 
has not finished primary education, are almost 6 times more likely to work than boys from households where the head of household holds a degree higher than junior secondary school; for girls this ratio is about 3. For all the levels of education we see child work incidence decreasing.

In line with the trends in child labor, Indonesia has shown strong improvements in education attainment over past decades, reaching almost universal primary school enrollment already in the mid 1980s (e.g., Jones and Hagul 2001, Lanjouw, Pradhan, Saadah, Sayed and Sparrow 2002). Indonesia's current 9 year basic education policy aims at achieving universal enrollment for children up to the age of 15 ; that is, up to junior secondary school. But while junior secondary school enrollment has certainly improved, the large drop out of around 30 percent in the transition from primary to junior secondary (around 70 percent) remains a problem. In particular striking are the relatively low transition rates among the poor. Among the poorest 20 percent of the population, almost half of the children that finish primary school drop out at junior secondary level; this is in stark contrast to the 12 percent drop out rate for the richest quintile (Paqueo and Sparrow 2006). Other problems that are still cause for concern are delayed enrollment and relatively high repetition rates, teacher quality and absenteeism, and lack of access to secondary schools in remote and rural areas (World Bank 2006).

In the remainder of this analysis we focus on child work activities by primary school age children close to the transition point, age 10 to 12, and junior secondary school age children, age 13 to 15. For children younger than 10 information on work is not available. 


\section{Data and empirical approach}

\subsection{Data}

Indonesia's national socio-economic household survey, Susenas, provides information on the outcome variables and socio-economic characteristics for individuals and households. The Susenas is conducted annually around January-February, typically sampling approximately 200,000 households, and is representative at the district level. The district will be our main unit of analysis, as districts take a key role as the main administrative units in Indonesia, and the regional labor markets are also best defined in district terms.

Districts are defined as municipalities (Kota) or predominantly rural areas (Kabupaten). Each district (both the Kota and Kabupaten) can be further divided into urban precincts (Kelurahan) and rural villages (Desa). It is important to emphasize the difference between these two urban/rural indicators, since we will use both variables in our analysis. A district classified as a rural Kabupaten mainly consists of rural villages, but may also include small towns that are registered as urban precincts in the data. In similar vein, districts classified as urban Kota mainly contain urban precincts and neighborhoods, but may also cover some rural areas at the fringes, which are then registered as villages. The exception are the five districts comprising the capital Jakarta, which are defined completely as urban. The Kota/Kabupaten classification will therefore appear as a fixed effect in our analysis, but we will also investigate the differential effects of tariff reduction for municipalities and rural districts. In addition, we will include the Desa/Kelurahan division as time variant control variable within districts.

The outcome variables record whether a child has worked in the last week. As mentioned earlier, market work is defined as activities that directly generate 
household income, irrespectively of whether it was performed at the formal labor market or within the family. We distinguish it from domestic work which consists of household chores only. The Susenas also provides information on education attainment of other household members, household composition, monthly household expenditure and sector of employment 13

The sectoral share of GDP per district is derived from the Regional GDP (GRDP) data of the Central Bureau of Statistics in Indonesia (BPS). The district GRDP are available from 1993 onward, and breaks down district GDP by 1 digit sector, of which the tradable sectors are agriculture, manufacturing and mining/quarrying. Information at lower level of aggregation is available (down to 3 digits), but the availability is not consistent over time.

Information on tariff lines comes from the UNCTAD-TRAINS database. These reflect the simple average of all applied tariff rates, which tend to be substantially lower than the bound tarrifs during the 1990s (WTO 1998, WTO 2003). As data on tariff lines is not available for some years (1994, 1997, and 1998), we use information from four three-year intervals (1993, 1996, 1999, and 2002) both in the pooled cross section and in the district panel. We can consistently match the relevant product categories to sectoral employment data derived from Susenas and the GRDP sectors at the 1 digit level.

We cannot include every district in our sample: Districts in Aceh, Maluku and Irian Jaya have not been included in the Susenas in some years due to violent conflict situations at the time of the survey. In addition, the 13 districts in East Timor were no longer covered by Susenas after the 1999 referendum on independence. We therefore drop these regions from the analysis. Another problem is that

\footnotetext{
13 The Susenas also collects data on schooling. But, unfortunately, the data on school attendance (which refers to the same recall period as the questions on child work activities) can not be used for this study as it is not consistent over time due to changes in the questionnaire between 1996 and 1999.
} 
over the period 1993 to 2002 some districts have split up over time. To keep time consistency in the district definitions, we redefine the districts to the 1993 parent district definitions.

Since the Susenas rounds are representative for the district population in each year, we construct a district panel by pooling the four annually repeated cross sections. This yields a balanced panel of 261 districts, which reduces to 244 districts when we merge the GRDP data, as GRDP information is not available for all districts. In addition to the pooled data, we also create a district pseudo-panel by computing district-level means for each variable, weighted by survey weights. The advantage of pooling the cross-section data is that we can work with individual level data and can account for individual heterogeneity, both in terms of characteristics and the impact of trade liberalization. For example, we are interested in the differential impact for high and low skilled labor, urban and rural areas, and gender. On the other hand, in the pseudo-panel the observation unit is the district which allows us to investigate dynamic effects at the district level. 14

Table 2 provides descriptive statistics. Pooling the four years of Susenas data yields a sample of 458,401 observations for children age 10 to 15 . The top panel of the table shows the outcome variables and the individual and household characteristics that we will use in the regressions. The bottom panel shows the descriptive statistics for the different tariff measures after they have been merged to the individual data. The tariff variables reflect a district's exposure to tariff protection based on either GRDP or employment shares. The table also reports the district specific poverty head count ratio $\left(P_{0}\right)$ and poverty severity $\left(P_{2}\right)$. The poverty measures are based on per capita expenditure data from Susenas and province-

\footnotetext{
14 In order to allow for heterogeneity in the district panel, we construct it not only for the whole sample but also for subsamples, divided by age, gender, and household head's education.
} 
urban/rural specific poverty lines 15

\subsection{Regional tariff exposure}

Following Topalova (2005) and Edmonds et al. (2007), tariff exposure measures are constructed by combining information on geographic variation in sector composition of the economy and temporal variation in tariff lines by product category. This yields a measure indicating how changes in exposure to tariff reductions varies by geographic area over the period 1993 to 2002 .

We extend this strategy by considering two alternative measures of economic structure at district level. First, similar to previous studies, we relate tariff changes to the employment shares of sectors within districts. This reflects how households are exposed to trade liberalization through local labor market dynamics. In addition to this, districts differ in relative exposure in terms of sector shares in district GRDP. These two measures may differ strongly, as agriculture typically has relatively high employment but low economic production shares, while the opposite holds for manufacturing. It is a priori not clear which measure will be more effective in capturing district exposure to trade liberalization. This will depend on the extent to which tariff changes are geared towards labor intensive industries.

For each sector $(h)$ the annual national tariff lines $T_{h t}$ for the relevant product categories are weighted by the 1993 sector shares in district $(k)$ GRDP or active

\footnotetext{
${ }^{15}$ Details on the method for construction of the poverty lines are described in Pradhan, Suryahadi, Sumarto and Pritchett (2001) and Suryahadi, Sumarto and Pritchett (2003).
} 
labor force $(L)$ :

$$
\begin{aligned}
T_{k t}^{G R D P} & =\sum_{h=1}^{H}\left(\frac{G R D P_{h k, 1993}}{G R D P_{k, 1993}} \times T_{h t}\right) \\
T_{k t}^{L} & =\sum_{h=1}^{H}\left(\frac{L_{h k, 1993}}{L_{k, 1993}} \times T_{h t}\right)
\end{aligned}
$$

The evolution of tariff protection, weighted by the GRDP and employment shares, is shown in Figure 6. Exposure is higher when the tariff lines are weighted by employment shares as compared to GRDP. This emphasizes the role of agriculture in terms of employment as compared to economic production.16

Since regionally representative data on the sectoral composition of households is usually available only at the one or the two-digit level, we cannot distinguish tariff reductions on locally produced import-competing goods from tariff reductions on goods which are not produced locally. Instead, our focus lies on the interactions between overall trade liberalization and the regional differences in economic structure, which determine the extent to which a region might be negatively affected by reductions in protection but also the extent to which it might be able to benefit from the efficiency gains associated with more competition in the local economy.

\subsection{Identification}

\subsubsection{Static analysis: pooled district panel}

Identification of the impact of tariff reductions relies on the geographic panel nature of the combined data, and in particular on the variation in tariff exposure over

\footnotetext{
${ }^{16}$ During the analyzed time-span, rice prices were regulated, as the national trading company (BULOG) had an import monopoly on rice, while export bans on rice were also effective. Given the governments control of rice import and export, we exempt rice production from tradable agricultural good production, and reduce the labor and GRDP shares in tradable agriculture by the share of rice fields in agricultural plantations within each district. We compute this latter information from the 1993 village agricultural census (PODES).
} 
districts and over time. We include district fixed effects $\left(\delta_{k}\right)$, while time-region fixed effects control for aggregate time trends $\left(\lambda_{r t}\right)$, allowing these to differ by the five main geographic areas of the archipelago: the islands of Java, Sumatra, Kalimantan and Sulawesi, and a cluster of smaller islands consisting of Bali and

the Nusa Tenggara group 17 We also include a set of time variant household and individual control variables $\left(\mathbf{X}_{i k t}\right)$ : age, gender and education of the household head, household size, and whether a household resides in an urban precinct or rural village (i.e. the Desa/Kelurahan composition of districts).

The main specification for the pooled district panel is

$$
\operatorname{Pr}\left(y_{i k t}=1\right)=\operatorname{Pr}\left(\alpha+\beta T_{k t}+\mathbf{X}_{i k t}^{\prime} \gamma+\lambda_{r t}+\delta_{k}+\epsilon_{i k t}>0\right)
$$

where $y_{i k t}$ reflects work activities for child $i$ in district $k$ at time $t$. We estimate the model separately for the municipalities and rural districts. The differential impact of trade liberalization is further explored by interacting the tariff exposure measure with the education of the head of household, as proxy for high or low skill labor.

\subsubsection{Potential sources of bias}

The main identifying assumption is that time variant shocks $\epsilon_{i k t}$ are orthogonal to $T_{k t}$. This would seem a reasonable assumption, given that $T_{k t}$ consists of the baseline economic structure and national changes in tariff regime. Thus, any temporal or regional variation endogenous to child work activities would be controlled for by time and geographic fixed effects. However, the identifying assumption would be violated if changes in district tariff exposure are endogenous to different local growth trajectories. Within the Indonesian context, regional variation

\footnotetext{
17 Although Bali is typically grouped with the economic center Java, we group the islands of Bali, NTT and NTB together because of close similarity of child work patterns on these islands.
} 
in growth trajectories may be partly determined by initial conditions regarding sectoral composition, in particular agriculture.

A first trend to note is that districts with a higher initial incidence of child labor experience larger decreases in child labor over time. This is reflected by Figure 7 a, which depicts a strong correlation between child work incidence in districts in 1993 and the decrease in child work from 1993 to 2002. With the bulk of child work located in agriculture, we would expect child work to decrease faster in districts with a relatively large share of the population active in agriculture and living in rural areas in 1993. These patterns are confirmed by Figure $7 \mathrm{~b}$ for the initial rural population share, Figure $7 \mathrm{c}$ for the initial agricultural labor force share and Figure 7fd for the the GRDP agriculture share.

Regional diversity in structural change from the primary to secondary and tertiary sectors and in economic outcomes is a prominent feature of Indonesia's economic geography. Hill, Resosudarmo and Vidyattama (2008) show evidence of strong regional variation in economic growth and structural change since the 1970s. However, they find only weak positive correlation between economic growth and structural change in districts. A related initial conditions problem, discussed at length by Edmonds et al. (2007), lies with the non-tradable sector. Districts may experience different growth paths, depending on the size of the non-tradable sector.

Since the initial sectoral composition of district economies is at the heart of $T_{k t}$, such differential trends in child labor could confound our estimates. We explore the scope of these confounding effects through an initial conditions sensitivity analysis and exploiting the panel features of the data. 


\subsubsection{Dynamic analysis: district pseudo-panel}

Collapsing the pooled district panel to a district pseudo-panel provides more options to further address the potential source of bias and allow a dynamic analysis, at the cost of losing the individual variation in the data. The district pseudo-panel analogue to (6) is

$$
\bar{y}_{k t}=\alpha+\beta T_{k t}+\overline{\mathbf{X}}_{i k t}^{\prime} \gamma+\lambda_{r t}+\delta_{k}+\bar{\epsilon}_{k t}
$$

where $\bar{y}_{k t}$ is the fraction of children in district $k$ that work in a given year $t$.

This specification is still prone to bias through time variant unobservables. However, with the fixed effects removed after a first-difference transformation of (7), it provides a first indicative test of exogeneity of tariff exposure. The assumption of strict exogeneity, $E\left\{T_{k t} \bar{\epsilon}_{k s}\right\}=0$ for all $s$ and $t$, implies that $T_{k t}$ should add no extra explanatory information in the regression

$$
\Delta \bar{y}_{k t}=\beta \Delta T_{k t}+\varphi T_{k t}+\Delta \overline{\mathbf{X}}_{i k t}^{\prime} \gamma+\lambda_{r t}+\Delta \bar{\epsilon}_{k t}
$$

which provides the testable hypothesis that $\varphi=0$.

As suggested by Edmonds et al. (2007), the scope of the bias related to initial conditions can be investigated further by introducing initial sector shares as control variables. We therefore add initial conditions interacted with year dummy variables to equation (8). Initial conditions are reflected by the 1993 labor and GDP shares (for specifications with $T^{L}$ and $T^{G D P}$, respectively) of the agriculture, mining, manufacturing, construction, trade, and transport sectors (with utilities as reference group), in addition to adult literacy rates in districts.

If our tariff measures are endogenous to child work, or if they capture differential trends in child work between districts, we would also expect child work to 
be correlated with future changes in district tariff exposure. We test this by regressing changes in $\bar{y}$ from 1993 to 1996 on changes in $T$ from 1999 to 2002 (i.e. $\left.\Delta T_{k t+2}\right)$.

Finally, we exploit the pseudo-panel fully by taking a dynamic specification, where we include a lagged dependent variable and lagged tariff measure.

$$
\bar{y}_{k t}=\beta T_{k t}+\phi T_{k t-1}+\theta \bar{y}_{k t-1}+\overline{\mathbf{X}}_{i k t}^{\prime} \gamma+\lambda_{r t}+\delta_{k}+\bar{\epsilon}_{k t}
$$

By including a lagged dependent variable we account for state dependence, and potential confounding differential trends in child labor between relatively high and low child labor districts. The lagged effects of tariff changes can identify short and long term effects. The immediate effect of a percentage point change in tariff exposure is reflected by $\beta$. The total long term change in $\bar{y}$ as a result of a percentage point change in tariff exposure, taking into account lagged effects of tariff changes and its dynamic multiplier effect trough $\bar{y}_{k t-1}$, is approximated by $(\beta+\phi) /(1-\theta)$

However, introducing a lagged dependent variable to the model compromises consistency of fixed effects estimates, in particular when the time dimension of the panel is limited. We therefore adopt a GMM approach to resolve any bias from the lagged dependent variable and potential endogeneity of tariff exposure. We apply an Arrelano-Bond (1991) difference GMM estimator, with a two-step Windmeijer (2005) correction.System estimation is not suitable as this requires the identifying assumption that the instruments are not correlated with the fixed effects. This is a problematic assumption since a main cause of concern for our analysis lies with the correlation of changes in child labor and tariffs with the initial characteristics of districts. This is also reflected in the Hansen over-identifying restrictions test results, which strongly reject the validity of the instruments in case 
of system GMM. We treat tariff exposure and the lagged dependent as endogenous, and adult literacy as pre-determined. First differences of these variables are then instrumented with their lagged levels 18

\section{Results}

\subsection{Static analysis}

We start by looking at the results from the static analysis, applying specification (6) to pooled cross section data. The estimated effects of tariff reductions on work are given in Table 3. The table only reports the coefficients for tariff exposure, omitting the other covariates for ease of presentation. These include a child's age and gender, household size, gender and education of the household head, and a dummy variable indicating whether a households resides in a rural village or urbanized precinct within the district.

The basic specification (model A) indicates that a decrease in tariff exposure is associated with a decrease in child work for 10 to 15 year old children, but the size of the effect varies between urban and rural areas and also depends on the nature of the exposure measure. A percentage point decrease in labor weighted tariff exposure leads to a 1.5 percentage point decrease in work incidence. This result is mainly driven by the effect in rural districts, where the estimates are larger and more precise than for municipalities (1.5 and 1.2 percentage points, respectively). The estimated effects are smaller for GRDP weighted tariff exposure, which would suggest that tariff changes affect households mainly through labor markets and less through distributional effects of economic growth.

\footnotetext{
18 The length of the panel (4 rounds) does not allow us to meaningfully address dynamic effects that go beyond one time lag. The number of instruments used in the estimations is $25, N$ is 488 for tariffs weighted by GRDP shares and 522 for tariffs weighted by labor shares.
} 
Model B investigates differential effects by skill level. The tariff exposure measure is interacted with the level of education of the head of household, defined as (i) not completed primary school, (ii) completed primary school, (iii) completed secondary school and (iv) completed higher education. The benefits of tariff reductions are relatively higher for low skill households.

\subsection{Sensitivity analysis and exogeneity tests}

The static results are based on district fixed effects, and could be confounding the effects of trade liberalization and differential growth paths. This section will examine this potential source of bias.

First, the pseudo-panel estimation results for both random and fixed effects specifications are presented in Table 4. As expected, the correlation between tariff exposure and the outcome variables is partly driven by time invariant characteristics of districts and changes in demographics and human capital. In general, controlling for fixed effects (columns (2) and (6)) reduces the tariff coefficients, compared to the random effects specification (columns (1) and (5)). Adding covariates yields specification (77), and further reduces the effects but improves the fit (columns (3) and (7)). The effects of tariff changes on child work remain precise and are consistent with the pooled cross section results, although the coefficients are slightly smaller.

Simple inclusion of the lagged tariff variable (columns (4) and (8)) indicates that immediate and longer-term effects of trade liberalization might differ, and that we may need to consider dynamic effects of tariff changes. While the labor share weighted results are not sensitive to including a one-period lag of tariff exposure, the GRDP weighted results show an initial large effect which is attenuated over time. 
The exogeneity of the tariff measures and sensitivity to initial conditions are therefore addressed more specifically in Table 5. Columns (1) to (4) show that the first difference estimates for child work resemble the fixed effects estimates presented earlier. The tests for strict exogeneity of tariffs exposure with respect to child work is given in column (2). For both the labor and GRDP weighted tariff measures the zero hypothesis of strict exogeneity is not rejected. The estimated effects on child work are also robust to including the initial conditions and year interaction terms in case of the labor share weighted tariffs (column (3)). The coefficients increase in size but lose precision when the interaction terms are included. Finally, we find no correlation between the two outcome variables and future tariff changes. The coefficients for two year lead changes in tariff exposure are small and not statistically significant.

The initial results from the district pseudo panel are fairly robust to specification, suggesting that the negative relationship between tariff reduction and child work is not driven by differential growth trajectories of district economies and the reduction of the agricultural sector. However, the results also indicate that the effects of trade liberalization are not static events but are dynamic in nature. These dynamics are overlooked in a simple fixed effect analysis, which may in fact capture the confounding result of short- and long-term impacts.

The economic crisis in 1997/98 also raises interpretational concerns, as the devaluation of the Rupiah resulted in short-term price spikes which affected especially the poor. Although the effect of the price spike has largely subsided by the 1999 Susenas round, and the overall negative effect of the crisis is controlled for by the region-time fixed effects included in every regression, concerns still might remain that the crisis might confound the effects of tariff reductions. This is especially the case if the effects of the crisis were correlated with the economic structure 
of the districts. In order to investigate these concerns, Table 6 reports difference estimates for two separated time periods: 1993-1996 (pre-crisis) and 1999-2002 (post-crisis). The results confirm the robustness of our findings on the effects of trade liberalization on child labor which are largely unaffected by the split.

\subsection{Dynamic analysis}

The main GMM estimation results for the dynamic specification are summarized in Table 719 $^{19}$ The results are presented by age group, gender and household head education level.

Decreasing district tariff exposure by one percentage point, leads to a shortterm decrease in child labor incidence of the 10-15 years old by $0.86-1.06$ percentage points depending on which tariff measure we use. Recursive substitution over the four periods gives us the overall effect of the decrease in local tariff exposure: when considering labor sector shares, the tariff reductions explain around half (49\%) of the average reduction of child labor of $8.98 \%$ points. The overall effect is even larger when tariff exposure is weighted by district GDP sector shares, explaining around $70 \%$ of the reductions. These figures clearly show that the local effects of tariff reductions are considerable, but because of the inclusion of region-year interactions, the magnitudes of these effects cannot be interpreted directly.

Reduction in child work due to tariff reductions are strongest in the age group of 13 to 15 years old, which is not surprising given the low incidence of child work among primary school age children. We do not see a gender gap, as the effects are

\footnotetext{
19 The full specification and detailed results are reported in the supplemental appendix, Table 11. Note that the Hansen over-identification test rejects the validity of the instruments at 10 percent level for the urban child work estimates. The Hansen test also rejects at 10 percent level for some of the sub-samples, in particular the youngest age group, boys and households with no educated head of household. Hence, these results need to be interpreted with some caution, although the previous analysis shows little evidence of endogeneity of tariff exposure with respect to child work.
} 
of comparable size for both girls and boys. When we consider tariff exposure based on district labor shares, improvements in child labor are irrespective of household skill composition, while children from relatively low skill households seem to be the main beneficiaries of trade liberalization based on the GDP sector shares of the local economy. When decomposing these effects for the rural and urban subsamples (cf. Table 8), it becomes apparent that these favorable effects are mainly rural, irrespective of the tariff weighting scheme.

Our study remains largely a reduced form analysis, and we are not able to identify the main transmission channels through which child work is affected by reduced tariff exposure. Nevertheless, we can provide some global indication of the main mechanisms at work, by looking at the effects on district poverty profiles and adult employment.

Tariff reductions have lead to a reduction in the extent and severity of poverty. Table 9 shows the estimated effects of reduced tariff exposure on the poverty head count ratio (Panel A) and the squared poverty gap (Panel B), where the model specification is similar to the earlier dynamic GMM. While the poverty head count merely records the fraction of the district population that cross an arbitrary level of consumption, the squared poverty gap reflects the curvature in the per capita expenditure distribution for the population living below the poverty line. The results show that a percentage point reduction in tariff exposure reduces the poverty headcount in districts by 1.2 percentage points, and also reduces inequality among the poor. In other words, the results seem to suggest that income effects play a role, in particular at the bottom end of the income distribution.

Tariff reductions do not impact workforce participation of cohorts older than 18 (cf. results in Table 10). This would suggest that the effect of trade liberalization on child labor is not driven by substitution of child for adult labor, and that the 
observed income effects are not due to a labor supply response and reduced unemployment. Rather, income effects seem to be a result of relative wage increases, in particular for low skill labor.

\section{Conclusion}

This paper examined the effects of trade liberalization on child work in Indonesia. In the 1990s, Indonesia went through a major reduction in tariff barriers, as average import tariff lines decreased from around 17.2 percent in 1993 to 6.6 percent in 2002; a period which also saw reductions in child work.

We identify the effects of trade liberalization by combining geographic variation in sector composition of the economy with temporal variation in tariff lines by product category. This yields geographic variation in changes in average exposure to trade liberalization over time, hence identifying geographical differences in the effects of trade policy. The results are robust to specification and sensitivity analysis, and we find no evidence of remaing sources of bias.

Our main findings suggest that Indonesia's trade liberalization experience in the 1990s has contributed to a strong decline in child labor, as decreased tariff exposure is associated with a decrease in work by 10 to 15 year old children. The effects of tariff reductions increase with the age of children, and are strongest for children from low skill backgrounds and in rural areas. Through these effects, trade liberalization will have long term welfare implications for human capital investments, in particular for low skill, and presumably poorer, households.

Although our reduced form analysis can at best provide indirect evidence of the main transmission channels, we do find strong support for the hypothesis that reduction of child labor is driven by positive income effects from trade liberalization 
for the poorest. This is consistent with other studies, which argue that trade liberalization in Indonesia brought about a relative wage increase for low skill labor, although causal effects are hard to confirm (Suryahadi 2001, Arnold and Smarzynska Javorcik 2005, Sitalaksmi et al. 2007). Further analysis of this causal relationship would be an area of future research.

The mixed empirical evidence from this paper and other country studies would suggest that the potential benefits to be gained from trade liberalization, and its distributional implications, are indeed context specific. The Indonesian context seems to have provided the pre-conditions needed to generate classic StolperSamuelson effects, partly facilitated by a coinciding process of structural change in the 1990s that saw a reallocation of labor from agriculture to services and manufacturing. In particular the mobility of low skill labor seems to play an important role, which, combined with increased productivity and competitiveness, has lead to better employment opportunities outside agriculture and increased returns to low skill labor. Such cross-country heterogeneinty may be underlying the weak average effects of trade liberalization on child labor and human capital investments found at macro level, highlighting the importance of considering local economic contexts when propagating trade reforms and formulating subsequent social policy responses. 


\section{References}

Amiti, M. and Konings, J.: 2007, Trade liberalization, intermediate inputs and productivity: Evidence from Indonesia, American Economic Review 97(5), 16111638.

Arellano, M. and Bond, S.: 1991, Some tests of specification for panel data: Monte Carlo evidence and an application to employment equations, Review of Economic Studies 58(2), 277-297.

Arnold, J. and Smarzynska Javorcik, B.: 2005, Gifted kids or pushy parents? Foreign acquisitions and plant performance in Indonesia, CEPR Discussion Papers 5065, C.E.P.R.

Basri, M. C. and Hill, H.: 2004, Ideas, interests and oil prices: The political economy of trade reform during Soeharto's Indonesia, The World Economy $27(5), 633-655$.

Basu, K. and Van, P. H.: 1998, The economics of child labor, American Economic Review 88(3), 412-427.

Beegle, K., Dehejia, R. H. and Gatti, R.: 2006, Child labor and agricultural shocks, Journal of Development Economics 81(1), 80-96.

Bhagwati, J. and Srinivasan, T. N.: 2002, Trade and poverty in the poor countries, American Economic Review 92(2), 180-183.

Cameron, L. A.: 2001, The impact of the Indonesian financial crisis on children: An analysis using the 100 villages survey, Bulletin of Indonesian Economic Studies 37(1), 43-64. 
Cigno, A., Rosati, F. C. and Guarcello, L.: 2002, Does globalisation increase child labour?, World Development 30(9), 1579-1589.

Davis, D. R. and Mishra, P.: 2007, Stolper-Samuelson is dead: And other crimes of both theory and data, in A. Harrison (ed.), Globalization and Poverty, NBER Chapters, National Bureau of Economic Research, Inc, pp. 87-108.

Edmonds, E. V. and Pavcnik, N.: 2005a, Child labor in a global economy, Journal of Economic Perspectives 8(1), 199-220.

Edmonds, E. V. and Pavcnik, N.: 2005b, The effect of trade liberalization on child labor, Journal of International Economics 65(2), 401-419.

Edmonds, E. V. and Pavcnik, N.: 2006, International trade and child labor: Cross-country evidence, Journal of International Economics 68(1), 115-140.

Edmonds, E. V., Pavcnik, N. and Topalova, P.: 2007, Trade adjustment and human capital investments: Evidence from Indian tariff reform, NBER Working Papers 12884, National Bureau of Economic Research, Inc.

Fane, G.: 1999, Indonesian economic policies and performance, 1960-98, The World Economy 22(5), 651-668.

Harrison, A.: 2007, Globalization and Poverty, NBER Books, University of Chicago Press for NBER.

Hertel, T. W., Ivanic, M., Preckel, P. V. and Cranfield, J. A. L.: 2004, The earnings effects of multilateral trade liberalization: Implications for poverty, The World Bank Economic Review 18(2), 205-236.

Hill, H., Resosudarmo, B. P. and Vidyattama, Y.: 2008, Indonesia's changing economic geography, Bulletin of Indonesian Economic Studies 44(3), 407435. 
Jafarey, S. and Lahiri, S.: 2002, Will trade sanctions reduce child labour?, Journal of Development Economics 68(1), 137-156.

Jones, G. W. and Hagul, P.: 2001, Schooling in Indonesia: Crisis-related and longer-term issues, Bulletin of Indonesian Economic Studies 37(2), 207-231.

Kis-Katos, K.: 2007, Does globalization reduce child labor?, Journal of International Trade and Economic Development 16(1), 71-92.

Kis-Katos, K. and Schulze, G.: 2009, Child labor in Indonesian small industries, Discussion Paper Series 10, University of Freiburg, Department of International Economic Policy.

Komiya, R.: 1967, Non-traded goods and the pure theory of international trade, International Economic Review 8(2), 132-152.

Lanjouw, P., Pradhan, M., Saadah, F., Sayed, H. and Sparrow, R.: 2002, Poverty, education and health in Indonesia: Who benefits from public spending?, in C. Morrisson (ed.), Education and Health Expenditures, and Development: The cases of Indonesia and Peru, OECD Development Centre, Paris, pp. 1778.

Manning, C.: 2000, The economic crisis and child labor in Indonesia, ILO/IPEC Working Paper, International Labour Office, Geneva.

Paqueo, V. and Sparrow, R.: 2006, Free basic education in Indonesia: Policy scenarios and implications for school enrolment, Mimeo, The World Bank, Jakarta.

Pradhan, M., Suryahadi, A., Sumarto, S. and Pritchett, L.: 2001, Eating like which "Joneses?" An iterative solution to the choice of a poverty line "reference group", Review of Income and Wealth 47(4), 473-487. 
Ranjan, P.: 2001, Credit constraints and the phenomenon of child labor, Journal of Development Economics 64(1), 81-102.

Sitalaksmi, S., Ismalina, P., Fitrady, A. and Robertson, R.: 2007, Globalization and working conditions: Evidence from Indonesia, Technical report, mimeo.

Suryahadi, A.: 2001, International economic integration and labor markets: The case of Indonesia, Economics Study Area Working Papers 22, East-West Center, Economics Study Area.

Suryahadi, A., Priyambada, A. and Sumarto, S.: 2005, Poverty, school and work: Children during the economic crisis in Indonesia, Development and Change 36(2), 351-373.

Suryahadi, A., Sumarto, S. and Pritchett, L.: 2003, Evolution of poverty during the crisis in Indonesia, Asian Economic Journal 17(3), 221-241.

Suryahadi, A., Suryadarma, D. and Sumarto, S.: 2009, The effects of location and sectoral components of economic growth on poverty: Evidence from Indonesia, Journal of Development Economics 89(1), 109-117.

Topalova, P.: 2005, Trade liberalization, poverty, and inequality: Evidence from Indian districts, NBER Working Papers 11614, National Bureau of Economic Research, Inc.

Windmeijer, F.: 2005, A finite sample correction for the variance of linear efficient two-step GMM estimators, Journal of Econometrics 126(1), 25-51.

World Bank: 2006, Making Indonesia Work for the Poor, World Bank Office Jakarta.

WTO: 1998, Trade Policy Review Indonesia, Geneva. 
WTO: 2003, Trade Policy Review Indonesia, Geneva. 


\section{A Tables}

Table 1: Evolution of market work of children over time

\begin{tabular}{|c|c|c|c|c|c|c|c|c|}
\hline \multirow[b]{2}{*}{ Year } & \multicolumn{8}{|c|}{ Share of boys aged 10-15 doing market work } \\
\hline & $\begin{array}{l}\text { By h } \\
\text { None } \\
\end{array}$ & $\begin{array}{c}\text { ad's educe } \\
\text { Primary }\end{array}$ & $\begin{array}{c}\text { tional atta } \\
\text { Low sec. }\end{array}$ & $\begin{array}{c}\text { nment } \\
\text { Higher }\end{array}$ & $\begin{array}{r}\text { By } \\
\text { Rural }\end{array}$ & $\begin{array}{l}\text { district } \\
\text { Urban } \\
\end{array}$ & Total & $N$ \\
\hline 1993 & 0.247 & 0.159 & 0.086 & 0.037 & 0.197 & 0.044 & 0.174 & 63,009 \\
\hline 1994 & 0.232 & 0.139 & 0.072 & 0.041 & 0.176 & 0.043 & 0.156 & 63,556 \\
\hline 1995 & 0.236 & 0.139 & 0.078 & 0.037 & 0.180 & 0.050 & 0.161 & 59,992 \\
\hline 1996 & 0.202 & 0.124 & 0.073 & 0.036 & 0.153 & 0.045 & 0.137 & 61,234 \\
\hline 1997 & 0.179 & 0.107 & 0.054 & 0.029 & 0.129 & 0.028 & 0.115 & 58,487 \\
\hline 1998 & 0.197 & 0.122 & 0.082 & 0.033 & 0.144 & 0.048 & 0.130 & 56,783 \\
\hline 1999 & 0.178 & 0.111 & 0.065 & 0.030 & 0.130 & 0.040 & 0.117 & 54,907 \\
\hline 2000 & 0.150 & 0.092 & 0.052 & 0.024 & 0.106 & 0.026 & 0.096 & 51,003 \\
\hline 2001 & 0.173 & 0.107 & 0.070 & 0.031 & 0.124 & 0.036 & 0.112 & 56,379 \\
\hline 2002 & 0.140 & 0.080 & 0.046 & 0.021 & 0.090 & 0.030 & 0.082 & 56,243 \\
\hline$N$ & 222,837 & 191,241 & 67,801 & 99,714 & 477,500 & 104,093 & 581,593 & 581,593 \\
\hline
\end{tabular}

Share of girls aged 10-15 doing market work

\begin{tabular}{lrrrrrrrr} 
& \multicolumn{9}{c}{ By head's educational attainment } & \multicolumn{2}{c}{ By district } \\
Year & None & Primary & Low sec. & Higher & Rural & Urban & Total & \multicolumn{1}{c}{$N$} \\
\cline { 2 - 9 } 1993 & 0.177 & 0.113 & 0.080 & 0.069 & 0.143 & 0.067 & 0.131 & 59,895 \\
1994 & 0.169 & 0.103 & 0.060 & 0.064 & 0.128 & 0.066 & 0.119 & 59,582 \\
1995 & 0.152 & 0.102 & 0.072 & 0.066 & 0.125 & 0.064 & 0.115 & 57,102 \\
1996 & 0.137 & 0.085 & 0.058 & 0.053 & 0.106 & 0.052 & 0.098 & 58,430 \\
1997 & 0.109 & 0.067 & 0.046 & 0.043 & 0.082 & 0.037 & 0.075 & 55,427 \\
1998 & 0.127 & 0.084 & 0.060 & 0.050 & 0.097 & 0.060 & 0.091 & 53,814 \\
1999 & 0.120 & 0.068 & 0.051 & 0.045 & 0.087 & 0.044 & 0.080 & 51,936 \\
2000 & 0.094 & 0.061 & 0.041 & 0.030 & 0.070 & 0.030 & 0.065 & 47,832 \\
2001 & 0.109 & 0.070 & 0.053 & 0.043 & 0.081 & 0.047 & 0.076 & 52,938 \\
2002 & 0.092 & 0.049 & 0.032 & 0.029 & 0.059 & 0.037 & 0.056 & 52,752 \\
$N$ & 207,841 & 180,188 & 64,162 & 97,517 & 447,531 & 102,177 & 549,708 & 549,708 \\
\hline
\end{tabular}

Notes: Participation shares are weighted by survey weights. $N$ refers to the number of observations in the sample, rural districts denote Kabupatens, urban districts denote Kotas. 


\section{Table 2: Descriptive statistics}

\begin{tabular}{lrrrrr}
\hline \multirow{2}{*}{ Variables } & No. obs. & Mean & St.dev. & Min. & Max. \\
\cline { 2 - 6 } & & & & & \\
PoolED: & & & & & 1 \\
Child market work & 458401 & 0.123 & 0.328 & 0 & 1 \\
Female & 458401 & 0.486 & 0.500 & 0 & 1.71 \\
Age & 458401 & 12.45 & 10 & 15 \\
Female head & 458401 & 0.081 & 0.272 & 0 & 1 \\
Household size & 458401 & 5.727 & 1.815 & 1 & 22 \\
Rural & 458401 & 0.668 & 0.471 & 0 & 1 \\
Head's ed.: primary & 458401 & 0.329 & 0.470 & 0 & 1 \\
Head's ed.: secondary & 458401 & 0.117 & 0.321 & 0 & 1 \\
Head's ed.: higher & 458401 & 0.174 & 0.379 & 0 & 1 \\
Tariff weighted by labor shares & 458401 & 5.416 & 3.086 & 0.176 & 14.90 \\
Tariff weighted by GRDP shares & 432161 & 4.441 & 2.356 & 0.160 & 13.85 \\
\cline { 2 - 6 } DistRICT PANEL (10-15 year olds): & & & & & \\
Child market work & 1044 & 0.121 & 0.080 & 0.011 & 0.488 \\
Average age & 1044 & 12.46 & 0.112 & 12.11 & 13.03 \\
Female share & 1044 & 0.487 & 0.027 & 0.385 & 0.598 \\
Rural share & 1044 & 0.646 & 0.317 & 0 & 1 \\
Share of hh-heads w/o education & 1044 & 0.376 & 0.160 & 0.028 & 0.848 \\
Tariff weighted by labor shares & 1044 & 5.264 & 3.080 & 0.176 & 14.90 \\
Tariff weighted by GRDP shares & 976 & 4.278 & 2.314 & 0.160 & 13.85 \\
Total population: & & & & & \\
Poverty headcount ratio $\left(P_{0}\right)$ & 1044 & 0.268 & 0.171 & 0 & 0.871 \\
Squared poverty gap $\left(P_{2}\right)$ & 1044 & 0.017 & 0.019 & 0 & 0.155 \\
\hline
\end{tabular}




\section{Table 3: Pooled results on child market work and tariff protection}

\begin{tabular}{|c|c|c|c|c|c|c|}
\hline \multirow{3}{*}{$\begin{array}{l}\text { Dependent } \\
\text { Tariffs weighted by } \\
\text { Districts }\end{array}$} & \multicolumn{6}{|c|}{ Child market work (10-15 year olds) } \\
\hline & \multicolumn{3}{|c|}{ Labor shares } & \multicolumn{3}{|c|}{ GRDP shares } \\
\hline & $\begin{array}{l}\text { All } \\
(1)\end{array}$ & $\begin{array}{c}\text { Rural } \\
(2)\end{array}$ & $\begin{array}{l}\text { Urban } \\
(3)\end{array}$ & $\begin{array}{l}\text { All } \\
(4)\end{array}$ & $\begin{array}{c}\text { Rural } \\
(5)\end{array}$ & $\begin{array}{l}\text { Urban } \\
(6)\end{array}$ \\
\hline $\begin{array}{l}\text { Model A } \\
\text { Tariff }\end{array}$ & $\begin{array}{r}0.0148^{* *} \\
(0.0015)\end{array}$ & $\begin{array}{r}0.0146^{* *} \\
(0.0032)\end{array}$ & $\begin{array}{r}0.0118 \dagger \\
(0.0011)\end{array}$ & $\begin{array}{c}0.0066^{*} \\
(0.0030)\end{array}$ & $\begin{array}{r}-0.0018 \\
(0.0034)\end{array}$ & $\begin{array}{r}0.0037 \\
(0.0033)\end{array}$ \\
\hline Adj. R2 & 0.132 & 0.137 & 0.052 & 0.130 & 0.136 & 0.052 \\
\hline $\begin{array}{l}\text { MoDEL B } \\
\text { Tariff } \times \\
\text { Head's ed.: none } \\
\text { Tariff } \times \\
\text { Head's ed.: primary } \\
\text { Tariff } \times \\
\text { Head's ed.: secondary } \\
\text { Tariff } \times \\
\text { Head's ed.: higher }\end{array}$ & $\begin{array}{r}0.0157^{* *} \\
(0.0015) \\
0.0133^{* *} \\
(0.0014) \\
0.0094^{* *} \\
(0.0014) \\
0.0037^{* *} \\
(0.0014)\end{array}$ & $\begin{array}{r}0.0155^{* *} \\
(0.0032) \\
0.0135^{* *} \\
(0.0031) \\
0.0103^{* *} \\
(0.0030) \\
0.0044 \\
(0.0030)\end{array}$ & $\begin{array}{r}0.0136^{*} \\
(0.0067) \\
0.0131 \dagger \\
(0.0068) \\
0.0072 \\
(0.0056) \\
0.0095 \\
(0.0069)\end{array}$ & $\begin{array}{r}0.0081^{* *} \\
(0.0030) \\
0.0062^{*} \\
(0.0030) \\
0.0036 \\
(0.0027) \\
0.0001 \\
(0.0022)\end{array}$ & $\begin{array}{r}-0.0003 \\
(0.0035) \\
-0.0022 \\
(0.0036) \\
-0.0031 \\
(0.0033) \\
-0.0060^{*} \\
(0.0026)\end{array}$ & $\begin{array}{r}0.0049 \\
(0.0037) \\
0.0059 \\
(0.0038) \\
0.0013 \\
(0.0030) \\
0.0022 \\
(0.0036)\end{array}$ \\
\hline Adj. R2 & 0.133 & 0.137 & 0.052 & 0.131 & 0.136 & 0.064 \\
\hline $\begin{array}{l}\text { In all models: } \\
\text { District fixed effects } \\
\text { Region } \times \text { year interactions }\end{array}$ & $\begin{array}{l}\text { Yes } \\
\text { Yes }\end{array}$ & $\begin{array}{l}Y e s \\
\text { Yes }\end{array}$ & $\begin{array}{l}Y e s \\
Y e s\end{array}$ & $\begin{array}{l}Y e s \\
Y e s\end{array}$ & $\begin{array}{l}\text { Yes } \\
\text { Yes }\end{array}$ & $\begin{array}{l}Y e s \\
Y e s\end{array}$ \\
\hline $\begin{array}{l}\text { Nr. obs. } \\
\text { Nr. districts }\end{array}$ & $\begin{array}{r}458,401 \\
261\end{array}$ & $\begin{array}{r}375,400 \\
209\end{array}$ & $\begin{array}{r}83,001 \\
52\end{array}$ & $\begin{array}{r}432,161 \\
244\end{array}$ & $\begin{array}{r}349,160 \\
192\end{array}$ & $\begin{array}{r}83,001 \\
52\end{array}$ \\
\hline
\end{tabular}

Notes: All models are estimated by OLS, weighted by sampling weights. Further controls include a full set of gender and age indicator interactions, household size, and dummies on heads' education, female head, and living in a rural neighborhood. For the divided samples, rural districts refer to Kabupatens, urban districts to Kotas. Standard errors (clustered at district level) are in parentheses. ${ }^{* *}, *, \dagger$ denote significance at the 1,5 , and $10 \%$ level. 


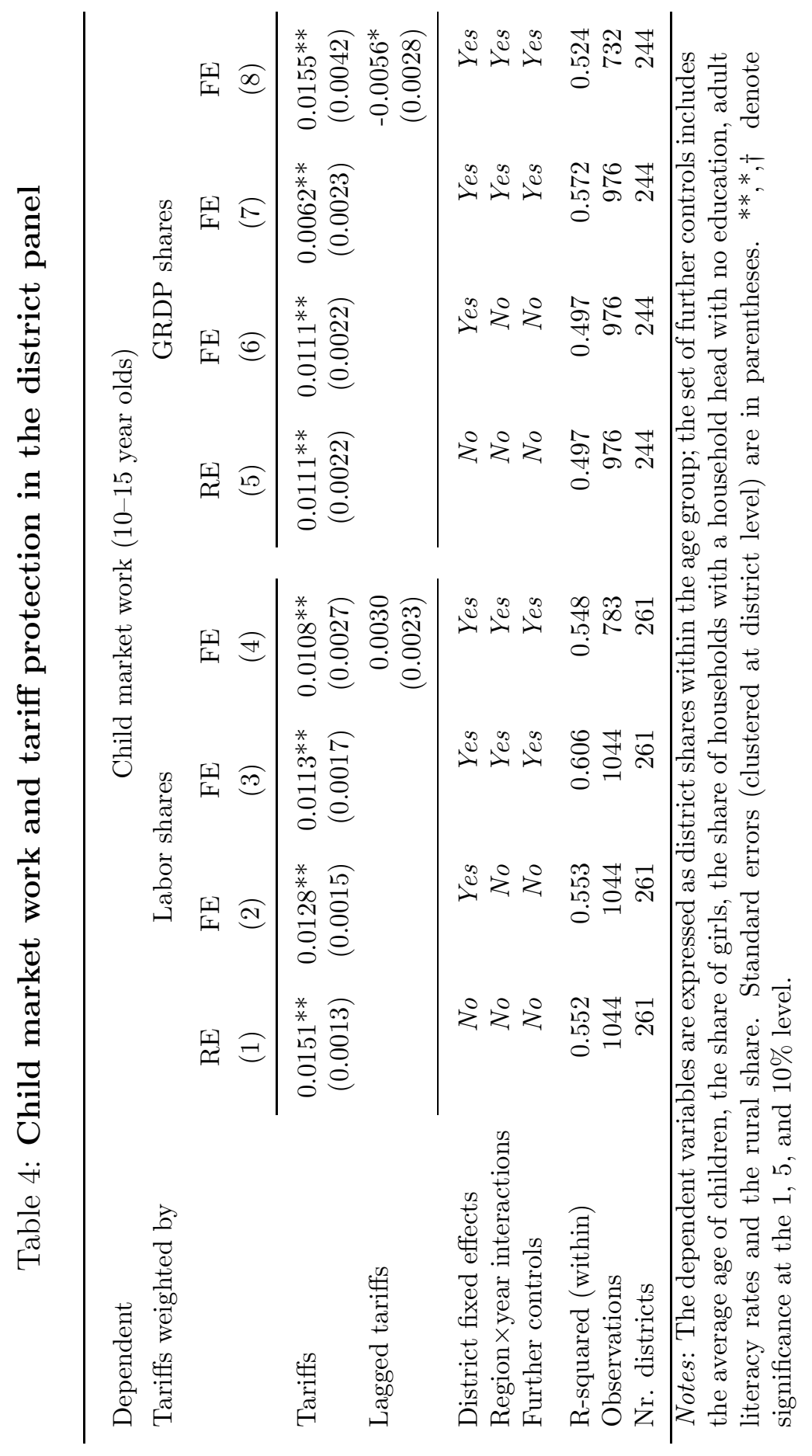




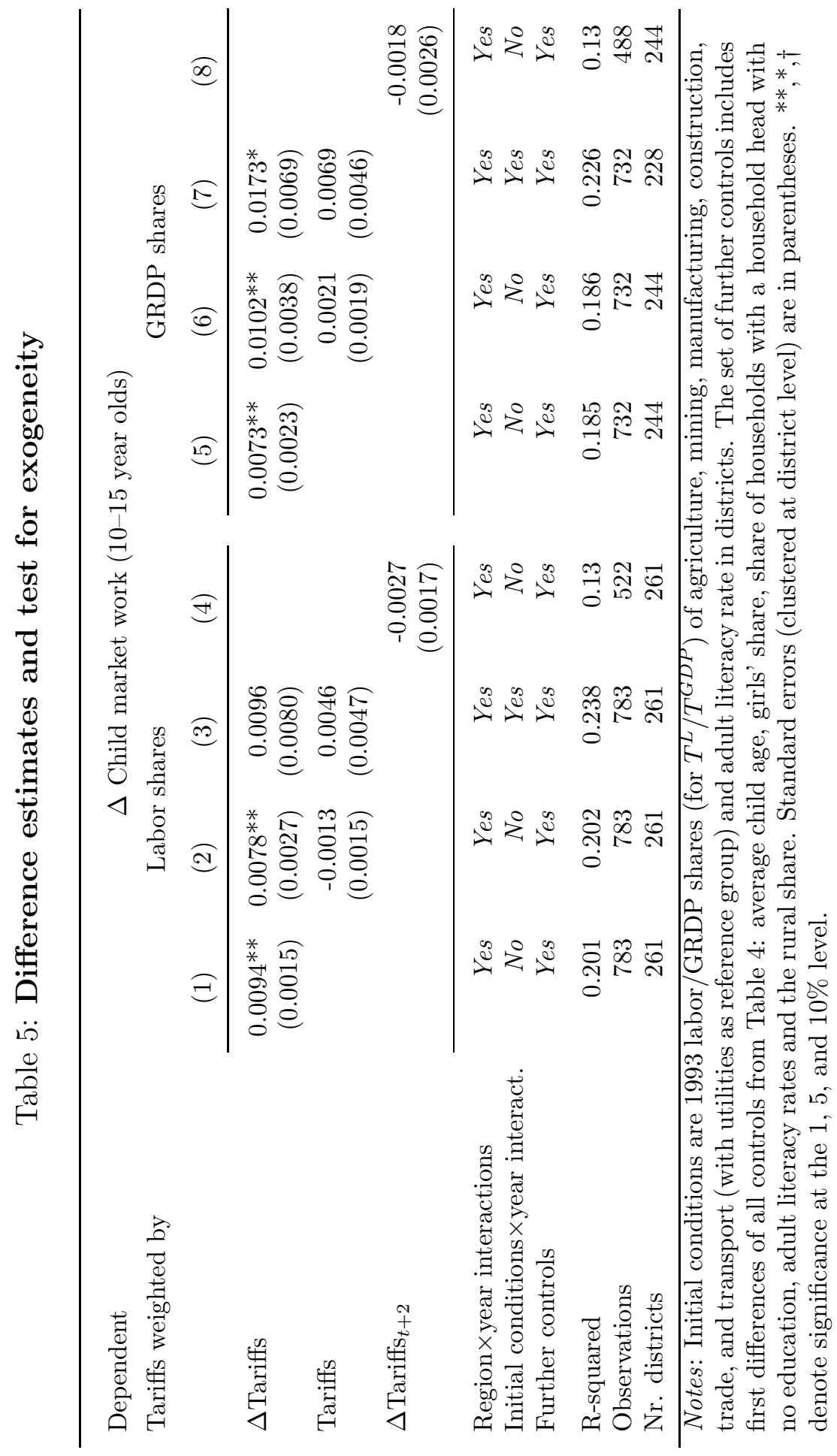


Table 6: Difference estimates by time period (1993-1996 and 1999-2002)

\begin{tabular}{|c|c|c|c|c|}
\hline Dependent & \multicolumn{4}{|c|}{$\Delta$ Child market work (10-15 year olds) } \\
\hline Tariffs weighted by & \multicolumn{2}{|c|}{ Labor shares } & \multicolumn{2}{|c|}{ GRDP shares } \\
\hline Time period & $\begin{array}{c}1993-1996 \\
\text { (1) }\end{array}$ & $\begin{array}{c}1999-2002 \\
(2)\end{array}$ & $\begin{array}{c}1993-1996 \\
(3)\end{array}$ & $\begin{array}{c}1999-2002 \\
(4)\end{array}$ \\
\hline$\Delta$ Tariffs & $\begin{array}{r}0.0088^{* *} \\
(0.0027)\end{array}$ & $\begin{array}{r}0.0110^{* *} \\
(0.0028)\end{array}$ & $\begin{array}{r}0.0045 \\
(0.0035)\end{array}$ & $\begin{array}{r}0.0127^{* *} \\
(0.0041)\end{array}$ \\
\hline $\begin{array}{l}\text { Region } \times \text { year interactions } \\
\text { Further controls }\end{array}$ & $\begin{array}{l}Y e s \\
Y e s\end{array}$ & $\begin{array}{l}Y e s \\
Y e s\end{array}$ & $\begin{array}{l}Y e s \\
Y e s\end{array}$ & $\begin{array}{l}Y e s \\
Y e s\end{array}$ \\
\hline $\begin{array}{l}\text { R-squared } \\
\text { Observations }\end{array}$ & $\begin{array}{r}0.136 \\
261\end{array}$ & $\begin{array}{r}0.245 \\
261\end{array}$ & $\begin{array}{r}0.107 \\
244\end{array}$ & $\begin{array}{r}0.318 \\
244\end{array}$ \\
\hline $\begin{array}{l}\text { Notes: The set of further } \\
\text { Table } 4 \text { average child age } \\
\text { head with no education, } \\
\text { errors (clustered at distric } \\
\text { at the } 1.5 \text { and } 10 \% \text { level }\end{array}$ & girtrols incl & $\begin{array}{l}\text { es first diffe } \\
\text { share of hor } \\
\text { rates and t }\end{array}$ & $\begin{array}{l}\text { ences of all } \\
\text { eholds with } \\
\text { rural shar }\end{array}$ & $\begin{array}{l}\text { ontrols from } \\
\text { household } \\
\text { Standard } \\
\text { significance }\end{array}$ \\
\hline
\end{tabular}




\section{Table 7: Child market work and tariff protection, GMM estimates}

\begin{tabular}{|c|c|c|c|c|c|c|}
\hline \multirow{3}{*}{$\begin{array}{l}\text { Dependent }\left(y_{t}\right) \\
\text { Tariffs weighted by }\end{array}$} & \multicolumn{6}{|c|}{ Child market work ( $10-15$ year olds) } \\
\hline & \multicolumn{3}{|c|}{ Labor shares } & \multicolumn{3}{|c|}{ GRDP shares } \\
\hline & $T_{t}$ & $T_{t-1}$ & $y_{t-1}$ & $T_{t}$ & $T_{t-1}$ & $y_{t-1}$ \\
\hline Age $10-15$ & $\begin{array}{r}0.0086^{* *} \\
(0.0028)\end{array}$ & $\begin{array}{r}-0.0026 \\
(0.0026)\end{array}$ & $\begin{array}{r}0.3876^{* *} \\
(0.1252)\end{array}$ & $\begin{array}{c}0.0106^{*} \\
(0.0043)\end{array}$ & $\begin{array}{c}-0.0085 \dagger \\
(0.0050)\end{array}$ & $\begin{array}{r}0.2794 \\
(0.1774)\end{array}$ \\
\hline Age $10-12$ & $\begin{array}{r}0.0058^{* *} \\
(0.0023)\end{array}$ & $\begin{array}{r}-0.0045 \\
(0.0022)\end{array}$ & $\begin{array}{c}0.3638^{*} \\
(0.1474)\end{array}$ & $\begin{array}{r}0.0064 \dagger \\
(0.0034)\end{array}$ & $\begin{array}{r}-0.0035 \\
(0.0041)\end{array}$ & $\begin{array}{r}0.2465 \\
(0.1885)\end{array}$ \\
\hline Age $13-15$ & $\begin{array}{r}0.0118^{* *} \\
(0.0040)\end{array}$ & $\begin{array}{r}-0.0006 \\
(0.0037)\end{array}$ & $\begin{array}{r}0.2368^{* *} \\
(0.0813)\end{array}$ & $\begin{array}{c}0.0161^{*} \\
(0.0063)\end{array}$ & $\begin{array}{c}-0.0143^{*} \\
(0.0068)\end{array}$ & $\begin{array}{r}0.1843 \\
(0.1167)\end{array}$ \\
\hline Male & $\begin{array}{r}0.0099 * * \\
(0.0033)\end{array}$ & $\begin{array}{r}-0.0044 \\
(0.0031)\end{array}$ & $\begin{array}{r}0.3482^{* *} \\
(0.1071)\end{array}$ & $\begin{array}{r}0.0110 \dagger \\
(0.0058)\end{array}$ & $\begin{array}{c}-0.0077 \dagger \\
(0.0041)\end{array}$ & $\begin{array}{r}0.2545 \\
(0.1288)\end{array}$ \\
\hline Female & $\begin{array}{c}0.0081^{*} \\
(0.0032)\end{array}$ & $\begin{array}{r}-0.0011 \\
(0.0028)\end{array}$ & $\begin{array}{r}0.3334^{* *} \\
(0.1124)\end{array}$ & $\begin{array}{r}0.0122^{* *} \\
(0.0049)\end{array}$ & $\begin{array}{r}-0.0053 \\
(0.0033)\end{array}$ & $\begin{array}{r}0.2995^{* *} \\
(0.1053)\end{array}$ \\
\hline No education hh-head & $\begin{array}{r}0.0165^{* *} \\
(0.0057)\end{array}$ & $\begin{array}{r}-0.0026 \\
(0.0038)\end{array}$ & $\begin{array}{c}0.3430^{* *} \\
(0.1040)\end{array}$ & $\begin{array}{r}0.0274^{* *} \\
(0.0094)\end{array}$ & $\begin{array}{c}-0.0119^{*} \\
(0.0052)\end{array}$ & $\begin{array}{r}0.2938^{* *} \\
(0.1133)\end{array}$ \\
\hline Primary hh-head & $\begin{array}{r}0.0107^{* *} \\
(0.0036)\end{array}$ & $\begin{array}{r}0.0011 \\
(0.0035)\end{array}$ & $\begin{array}{c}0.2149^{*} \\
(0.0935)\end{array}$ & $\begin{array}{c}0.0126^{*} \\
(0.0053)\end{array}$ & $\begin{array}{r}-0.0015 \\
(0.0040)\end{array}$ & $\begin{array}{c}0.2454^{*} \\
(0.0963)\end{array}$ \\
\hline Junior Secondary hh-head & $\begin{array}{r}0.0100^{*} \\
(0.0041)\end{array}$ & $\begin{array}{r}0.0050 \\
(0.0043)\end{array}$ & $\begin{array}{r}0.0352 \\
(0.0848)\end{array}$ & $\begin{array}{r}0.0041 \\
(0.0054)\end{array}$ & $\begin{array}{r}-0.0002 \\
(0.0044)\end{array}$ & $\begin{array}{r}0.0577 \\
(0.0978)\end{array}$ \\
\hline Senior Secondary hh-head & $\begin{array}{c}0.0169^{*} \\
(0.0067)\end{array}$ & $\begin{array}{r}-0.0070 \\
(0.0055)\end{array}$ & $\begin{array}{r}0.1125 \dagger \\
(0.0661)\end{array}$ & $\begin{array}{r}0.0055 \\
(0.0039)\end{array}$ & $\begin{array}{r}0.0001 \\
(0.0027)\end{array}$ & $\begin{array}{r}0.1312 \dagger \\
(0.0742)\end{array}$ \\
\hline
\end{tabular}

Notes: Coefficients from difference GMM estimates on tariffs and lagged market work are presented in rows for different subsamples of children (by age, gender and household head's education). All models include region and time interactions, average age, share of females (where applicable), rural share, adult literacy, and the share of unskilled headed families (where applicable). Standard errors (clustered at district level) are in parentheses. $N=522$ for tariffs weighted by labor shares, and $N=488$ for tariffs weighted by GRDP shares. ${ }^{* *},{ }^{*}, \dagger$ denote significance at the 1,5 , and $10 \%$ level. 
Table 8: Child market work and tariff protection, GMM estimates

\begin{tabular}{|c|c|c|c|c|c|c|}
\hline \multirow{3}{*}{$\begin{array}{l}\text { Dependent }\left(y_{t}\right) \\
\text { Tariffs weighted by }\end{array}$} & \multicolumn{6}{|c|}{ Child market work (10-15 year olds) } \\
\hline & \multicolumn{3}{|c|}{ Labor shares } & \multicolumn{3}{|c|}{ GRDP shares } \\
\hline & $T_{t}$ & $T_{t-1}$ & $y_{t-1}$ & $T_{t}$ & $T_{t-1}$ & $y_{t-1}$ \\
\hline \multicolumn{7}{|l|}{ RURAL DISTRICTS: } \\
\hline Age $10-15$ & $\begin{array}{r}0.0171^{* *} \\
(0.0066)\end{array}$ & $\begin{array}{r}-0.0059 \\
(0.0044)\end{array}$ & $\begin{array}{r}0.3884^{* *} \\
(0.1461)\end{array}$ & $\begin{array}{c}0.0170^{*} \\
(0.0086)\end{array}$ & $\begin{array}{l}-0.0085 \dagger \\
(0.0050)\end{array}$ & $\begin{array}{r}0.2794 \\
(0.1774)\end{array}$ \\
\hline Age 10-12 & $\begin{array}{r}0.0088 \\
(0.0055)\end{array}$ & $\begin{array}{r}-0.0057 \\
(0.0040)\end{array}$ & $\begin{array}{c}0.3864^{*} \\
(0.1726)\end{array}$ & $\begin{array}{r}0.0071 \\
(0.0072)\end{array}$ & $\begin{array}{r}-0.0035 \\
(0.0041)\end{array}$ & $\begin{array}{r}0.2465 \\
(0.1885)\end{array}$ \\
\hline Age 13-15 & $\begin{array}{r}0.0264^{* *} \\
(0.0089)\end{array}$ & $\begin{array}{r}-0.0081 \\
(0.0063)\end{array}$ & $\begin{array}{r}0.2206^{* *} \\
(0.0949)\end{array}$ & $\begin{array}{c}0.0268^{*} \\
(0.0121)\end{array}$ & $\begin{array}{c}-0.0143^{*} \\
(0.0068)\end{array}$ & $\begin{array}{r}0.1843 \\
(0.1167)\end{array}$ \\
\hline Male & $\begin{array}{r}0.0149 \dagger \\
(0.0079)\end{array}$ & $\begin{array}{r}-0.0061 \\
(0.0056)\end{array}$ & $\begin{array}{r}0.3568^{* *} \\
(0.1281)\end{array}$ & $\begin{array}{r}0.0104 \\
(0.0092)\end{array}$ & $\begin{array}{r}-0.0089 \\
(0.0064)\end{array}$ & $\begin{array}{r}0.2064 \\
(0.1600)\end{array}$ \\
\hline Female & $\begin{array}{c}0.0171^{*} \\
(0.0075)\end{array}$ & $\begin{array}{r}-0.0058 \\
(0.0054)\end{array}$ & $\begin{array}{r}0.3162^{* *} \\
(0.1228)\end{array}$ & $\begin{array}{r}0.0221^{* *} \\
(0.0092)\end{array}$ & $\begin{array}{r}-0.0086 \dagger \\
(0.0052)\end{array}$ & $\begin{array}{c}0.2693^{*} \\
(0.1214)\end{array}$ \\
\hline No education hh-head & $\begin{array}{c}0.0226^{*} \\
(0.0098)\end{array}$ & $\begin{array}{r}-0.0088 \\
(0.0058)\end{array}$ & $\begin{array}{c}0.2925^{*} \\
(0.1368)\end{array}$ & $\begin{array}{r}0.0278^{*} \\
(0.0138)\end{array}$ & $\begin{array}{c}-0.0145^{*} \\
(0.0072)\end{array}$ & $\begin{array}{r}0.1616 \\
(0.1351)\end{array}$ \\
\hline Primary hh-head & $\begin{array}{r}0.0129 \dagger \\
(0.0072)\end{array}$ & $\begin{array}{r}-0.0025 \\
(0.0059)\end{array}$ & $\begin{array}{c}0.2329^{*} \\
(0.1043)\end{array}$ & $\begin{array}{r}0.0147 \\
(0.0090)\end{array}$ & $\begin{array}{r}-0.0025 \\
(0.0060)\end{array}$ & $\begin{array}{c}0.2315^{*} \\
(0.1126)\end{array}$ \\
\hline Junior Secondary hh-head & $\begin{array}{r}0.0124 \dagger \\
(0.0069)\end{array}$ & $\begin{array}{r}0.0053 \\
(0.0070)\end{array}$ & $\begin{array}{r}0.0247 \\
(0.0883)\end{array}$ & $\begin{array}{r}0.0072 \\
(0.0093)\end{array}$ & $\begin{array}{r}-0.0021 \\
(0.0077)\end{array}$ & $\begin{array}{r}0.0392 \\
(0.1028)\end{array}$ \\
\hline Senior Secondary hh-head & $\begin{array}{r}0.0243^{* *} \\
(0.0093)\end{array}$ & $\begin{array}{r}-0.0115 \\
(0.0078)\end{array}$ & $\begin{array}{r}0.1085 \\
(0.0697)\end{array}$ & $\begin{array}{r}0.0103 \\
(0.0068)\end{array}$ & $\begin{array}{r}-0.0026 \\
(0.0044)\end{array}$ & $\begin{array}{r}0.1361 \dagger \\
(0.0799)\end{array}$ \\
\hline \multicolumn{7}{|l|}{ URBAN DISTRICTS: } \\
\hline Age $10-15$ & $\begin{array}{r}-0.0128 \\
(0.0159)\end{array}$ & $\begin{array}{r}0.0058 \\
(0.0120)\end{array}$ & $\begin{array}{r}0.1274 \\
(0.2058)\end{array}$ & $\begin{array}{r}-0.0033 \\
(0.0068)\end{array}$ & $\begin{array}{r}-0.0036 \\
(0.0040)\end{array}$ & $\begin{array}{r}0.1015 \\
(0.1550)\end{array}$ \\
\hline Age $10-12$ & $\begin{array}{r}-0.0119 \\
(0.0123)\end{array}$ & $\begin{array}{r}-0.0008 \\
(0.0092)\end{array}$ & $\begin{array}{r}0.0547 \\
(0.1349)\end{array}$ & $\begin{array}{r}-0.0006 \\
(0.0070)\end{array}$ & $\begin{array}{r}-0.0023 \\
(0.0050)\end{array}$ & $\begin{array}{r}0.0264 \\
(0.1071)\end{array}$ \\
\hline Age 13-15 & $\begin{array}{r}-0.0275 \\
(0.0304)\end{array}$ & $\begin{array}{r}0.0140 \\
(0.0206)\end{array}$ & $\begin{array}{r}0.1648 \\
(0.1816)\end{array}$ & $\begin{array}{r}-0.0087 \\
(0.0128)\end{array}$ & $\begin{array}{r}-0.0050 \\
(0.0060)\end{array}$ & $\begin{array}{r}0.1482 \\
(0.1599)\end{array}$ \\
\hline Male & $\begin{array}{r}-0.0102 \\
(0.0204)\end{array}$ & $\begin{array}{r}0.0061 \\
(0.0110)\end{array}$ & $\begin{array}{r}-0.0151 \\
(0.1801)\end{array}$ & $\begin{array}{r}-0.0037 \\
(0.0091)\end{array}$ & $\begin{array}{r}-0.0015 \\
(0.0048)\end{array}$ & $\begin{array}{r}-0.0250 \\
(0.1628)\end{array}$ \\
\hline Female & $\begin{array}{r}-0.0110 \\
(0.0195)\end{array}$ & $\begin{array}{r}0.0071 \\
(0.0184)\end{array}$ & $\begin{array}{r}0.1765 \\
(0.1623)\end{array}$ & $\begin{array}{r}-0.0009 \\
(0.0067)\end{array}$ & $\begin{array}{r}-0.0056 \\
(0.0046)\end{array}$ & $\begin{array}{r}0.1810 \\
(0.1428)\end{array}$ \\
\hline No education hh-head & $\begin{array}{r}0.0082 \\
(0.0200)\end{array}$ & $\begin{array}{r}0.0090 \\
(0.0135)\end{array}$ & $\begin{array}{r}0.3298^{* *} \\
(0.1157)\end{array}$ & $\begin{array}{r}0.0248 \\
(0.0255)\end{array}$ & $\begin{array}{r}-0.0145 \\
(0.0117)\end{array}$ & $\begin{array}{r}0.3180 * * \\
(0.1206)\end{array}$ \\
\hline Primary hh-head & $\begin{array}{r}-0.0044 \\
(0.0120)\end{array}$ & $\begin{array}{r}0.0020 \\
(0.0132)\end{array}$ & $\begin{array}{r}-0.1555 \\
(0.1232)\end{array}$ & $\begin{array}{r}-0.0058 \\
(0.0082)\end{array}$ & $\begin{array}{r}-0.0002 \\
(0.0064)\end{array}$ & $\begin{array}{r}-0.1647 \\
(0.1195)\end{array}$ \\
\hline Junior Secondary hh-head & $\begin{array}{r}-0.0267 \\
(0.0264)\end{array}$ & $\begin{array}{r}0.0179 \dagger \\
(0.0099)\end{array}$ & $\begin{array}{r}-0.0760 \\
(0.0963)\end{array}$ & $\begin{array}{r}-0.0185 \\
(0.0180)\end{array}$ & $\begin{array}{r}0.0047 \\
(0.0068)\end{array}$ & $\begin{array}{r}-0.0824 \\
(0.0993)\end{array}$ \\
\hline Senior Secondary hh-head & $\begin{array}{r}-0.0112 \\
(0.0255)\end{array}$ & $\begin{array}{r}0.0093 \\
(0.0159)\end{array}$ & $\begin{array}{r}-0.1498 \\
(0.1131)\end{array}$ & $\begin{array}{r}0.0049 \\
(0.0081)\end{array}$ & $\begin{array}{r}-0.0037 \\
(0.0048)\end{array}$ & $\begin{array}{r}-0.1804 \\
(0.1134)\end{array}$ \\
\hline
\end{tabular}

Notes: Coefficients from difference GMM estimates on tariffs and lagged market work are presented in rows for different subsamples of children (by age, gender and household head's education). All models include region and time interactions, average age, share of females (where applicable), rural share, adult literacy, and the share of unskilled headed families (where applicable). Standard errors (clustered at district level) are in parentheses. $N=522$ for tariffs weighted by labor shares, and $N=488$ for tariffs weighted by GRDP shares. ${ }^{* *},{ }^{*}, \dagger$ denote significance at the 1,5 , and $10 \%$ level. 
Table 9: Tariff reductions and poverty, GMM estimates

\begin{tabular}{|c|c|c|c|c|c|c|}
\hline \multirow[t]{2}{*}{ Tariffs weighted by } & \multicolumn{3}{|c|}{ Labor shares } & \multicolumn{3}{|c|}{ GRDP shares } \\
\hline & $T_{t}$ & $T_{t-1}$ & $y_{t-1}$ & $T_{t}$ & $T_{t-1}$ & $y_{t-1}$ \\
\hline \multicolumn{7}{|c|}{ PANEL A: Dependent $\left(y_{t}\right)$ : Poverty headcount ratio $\left(P_{0}\right)$} \\
\hline Total sample & $\begin{array}{c}0.0118^{*} \\
(0.0058)\end{array}$ & $\begin{array}{r}-0.0036 \\
(0.0049)\end{array}$ & $\begin{array}{r}-0.0988 \\
(0.0974)\end{array}$ & $\begin{array}{r}0.0163 \\
(0.0106)\end{array}$ & $\begin{array}{c}-0.0115 \dagger \\
(0.0061)\end{array}$ & $\begin{array}{r}-0.0428 \\
(0.0971)\end{array}$ \\
\hline Rural districts & $\begin{array}{r}0.0146 \\
(0.0094)\end{array}$ & $\begin{array}{r}0.0110 \\
(0.0079)\end{array}$ & $\begin{array}{r}-0.1492 \\
(0.1093)\end{array}$ & $\begin{array}{r}-0.0031 \\
(0.0178)\end{array}$ & $\begin{array}{r}-0.0082 \\
(0.0108)\end{array}$ & $\begin{array}{r}-0.0754 \\
(0.1126)\end{array}$ \\
\hline Urban districts & $\begin{array}{r}0.0404 \\
(0.0407)\end{array}$ & $\begin{array}{r}-0.0249 \\
(0.0258)\end{array}$ & $\begin{array}{c}-0.3854^{*} \\
(0.1841)\end{array}$ & $\begin{array}{r}0.0454 \\
(0.0327)\end{array}$ & $\begin{array}{r}-0.0153 \\
(0.0165)\end{array}$ & $\begin{array}{c}-0.3549^{*} \\
(0.1556)\end{array}$ \\
\hline \multicolumn{7}{|c|}{ PANel B: Dependent $\left(y_{t}\right):$ Squared poverty gap $\left(P_{2}\right)$} \\
\hline Total sample & $\begin{array}{r}0.0021^{* *} \\
(0.0008)\end{array}$ & $\begin{array}{r}-0.0010 \\
(0.0006)\end{array}$ & $\begin{array}{r}0.0691 \\
(0.1642)\end{array}$ & $\begin{array}{r}0.0025 \\
(0.0014)\end{array}$ & $\begin{array}{r}-0.0017 \\
(0.0008)\end{array}$ & $\begin{array}{r}0.0650 \\
(0.1821)\end{array}$ \\
\hline Rural districts & $\begin{array}{r}0.0036 \dagger \\
(0.0020)\end{array}$ & $\begin{array}{r}-0.0015 \\
(0.0013)\end{array}$ & $\begin{array}{r}0.0785 \\
(0.1565)\end{array}$ & $\begin{array}{r}-0.0001 \\
(0.0030)\end{array}$ & $\begin{array}{r}-0.0008 \\
(0.0014)\end{array}$ & $\begin{array}{r}0.0650 \\
(0.1821)\end{array}$ \\
\hline Urban districts & $\begin{array}{r}-0.0001 \\
(0.0029)\end{array}$ & $\begin{array}{c}-0.0005 \\
(0.0024)\end{array}$ & $\begin{array}{r}-0.5436^{* *} \\
(0.1699)\end{array}$ & $\begin{array}{r}0.0021 \\
(0.0030)\end{array}$ & $\begin{array}{r}-0.0011 \\
(0.0018)\end{array}$ & $\begin{array}{r}-0.5286^{* *} \\
(0.1491)\end{array}$ \\
\hline
\end{tabular}

Notes: Coefficients from difference GMM estimates on tariffs and lagged dependent are presented in rows (for the total sample, rural and urban districts). All models include region and time interactions, rural share, lagged per capita GRDP and adult literacy. The lagged dependent, tariffs, rural share, lagged pc. GRDP and literacy are treated as endogenous and instrumented in GMM style. Standard errors (clustered at district level) are in parentheses. $N$ is 508(474) in the total, 416(382) in the rural and 92(92) in the urban sample for tariffs weighted by labor (GRDP) shares. ${ }^{* *},+\dagger$ denote significance at the 1,5 , and $10 \%$ level. 


\section{Table 10: Market work by age cohorts, GMM estimates}

\begin{tabular}{|c|c|c|c|c|c|c|}
\hline \multirow{3}{*}{$\begin{array}{l}\text { Dependent }\left(y_{t}\right) \\
\text { Tariffs weighted by }\end{array}$} & \multicolumn{6}{|c|}{ Market work in the given age group } \\
\hline & \multicolumn{3}{|c|}{ Labor shares } & \multicolumn{3}{|c|}{ GRDP shares } \\
\hline & $T_{t}$ & $T_{t-1}$ & $y_{t-1}$ & $T_{t}$ & $T_{t-1}$ & $y_{t-1}$ \\
\hline Aged 10-12 & $\begin{array}{r}0.0058^{* *} \\
(0.0023)\end{array}$ & $\begin{array}{c}-0.0045^{*} \\
(0.0022)\end{array}$ & $\begin{array}{r}0.3638^{* *} \\
(0.1474)\end{array}$ & $\begin{array}{r}0.0064 \dagger \\
(0.0034)\end{array}$ & $\begin{array}{r}-0.0039 \\
(0.0027)\end{array}$ & $\begin{array}{r}0.2366 \\
(0.1655)\end{array}$ \\
\hline Aged 13-15 & $\begin{array}{r}0.0118^{* *} \\
(0.0040)\end{array}$ & $\begin{array}{r}-0.0006 \\
(0.0037)\end{array}$ & $\begin{array}{r}0.2368^{* *} \\
(0.0813)\end{array}$ & $\begin{array}{r}0.0161^{* *} \\
(0.0063)\end{array}$ & $\begin{array}{c}-0.0088^{*} \\
(0.0043)\end{array}$ & $\begin{array}{r}0.2608^{* *} \\
(0.0845)\end{array}$ \\
\hline Aged 16-18 & $\begin{array}{r}0.0109^{* *} \\
(0.0041)\end{array}$ & $\begin{array}{r}0.0023 \\
(0.0040)\end{array}$ & $\begin{array}{r}0.1331 \\
(0.0934)\end{array}$ & $\begin{array}{r}0.0105 \\
(0.0079)\end{array}$ & $\begin{array}{r}-0.0048 \\
(0.0053)\end{array}$ & $\begin{array}{c}0.2161^{*} \\
(0.0960)\end{array}$ \\
\hline Aged 19-24 & $\begin{array}{r}0.0067 \\
(0.0034)\end{array}$ & $\begin{array}{r}0.0022 \\
(0.0034)\end{array}$ & $\begin{array}{r}0.0524 \\
(0.0848)\end{array}$ & $\begin{array}{r}0.0007 \\
(0.0062)\end{array}$ & $\begin{array}{r}-0.0015 \\
(0.0053)\end{array}$ & $\begin{array}{r}0.0500 \\
(0.0889)\end{array}$ \\
\hline Aged 25-30 & $\begin{array}{r}0.0002 \\
(0.0036)\end{array}$ & $\begin{array}{r}0.0019 \\
(0.0032)\end{array}$ & $\begin{array}{c}0.2121^{*} \\
(0.0953)\end{array}$ & $\begin{array}{r}-0.0017 \\
(0.0056)\end{array}$ & $\begin{array}{r}-0.0006 \\
(0.0040)\end{array}$ & $\begin{array}{r}0.2221^{* *} \\
(0.0910)\end{array}$ \\
\hline Aged 31-40 & $\begin{array}{r}0.0004 \\
(0.0026)\end{array}$ & $\begin{array}{r}-0.0003 \\
(0.0022)\end{array}$ & $\begin{array}{r}0.2351^{* *} \\
(0.0994)\end{array}$ & $\begin{array}{r}-0.0045 \\
(0.0043)\end{array}$ & $\begin{array}{r}-0.0008 \\
(0.0030)\end{array}$ & $\begin{array}{r}0.2597^{* *} \\
(0.0967)\end{array}$ \\
\hline Aged $41-60$ & $\begin{array}{r}-0.0011 \\
(0.0027)\end{array}$ & $\begin{array}{r}0.0016 \\
(0.0021)\end{array}$ & $\begin{array}{r}0.1968^{* *} \\
(0.0823)\end{array}$ & $\begin{array}{r}-0.0069 \\
(0.0043)\end{array}$ & $\begin{array}{r}0.0020 \\
(0.0028)\end{array}$ & $\begin{array}{r}0.2180^{* *} \\
(0.0849)\end{array}$ \\
\hline
\end{tabular}

Notes: Coefficients from difference GMM estimates on tariffs and lagged market work are presented in rows for different subsamples of children and adults (by age). All models include region and time interactions, average age, share of females, rural share, adult literacy, and the share of unskilled headed families. Standard errors (clustered at district level) are in parentheses. $N=522$ for tariffs weighted by labor shares, and $N=488$ for tariffs weighted by GRDP shares. ${ }^{* *},{ }^{*}, \dagger$ denote significance at the 1, 5, and $10 \%$ level. 


\section{Supplemental tables}

\section{Table 11: Child market work and tariff protection, full GMM results}

\begin{tabular}{|c|c|c|c|c|c|c|}
\hline \multirow{3}{*}{$\begin{array}{l}\text { Dependent }\left(y_{t}\right) \\
\text { Tariffs weighted by } \\
\text { Districts }\end{array}$} & \multicolumn{6}{|c|}{ Child market work (10-15 year olds) } \\
\hline & \multicolumn{3}{|c|}{ Labor shares } & \multicolumn{3}{|c|}{ GRDP shares } \\
\hline & $\begin{array}{l}\text { All } \\
(1)\end{array}$ & $\begin{array}{c}\text { Rural } \\
(2)\end{array}$ & $\begin{array}{c}\text { Urban } \\
(3)\end{array}$ & $\begin{array}{l}\text { All } \\
(4)\end{array}$ & $\begin{array}{c}\text { Rural } \\
(5)\end{array}$ & $\begin{array}{c}\text { Urban } \\
\quad(6)\end{array}$ \\
\hline Tariffs & $\begin{array}{r}0.0086^{* *} \\
(0.0028)\end{array}$ & $\begin{array}{r}0.0171^{* *} \\
(0.0066)\end{array}$ & $\begin{array}{c}-0.0128 \\
(0.0159)\end{array}$ & $\begin{array}{c}0.0106^{*} \\
(0.0043)\end{array}$ & $\begin{array}{c}0.0170^{*} \\
(0.0086)\end{array}$ & $\begin{array}{r}-0.0033 \\
(0.0068)\end{array}$ \\
\hline Lagged tariffs & $\begin{array}{r}-0.0026 \\
(0.0026)\end{array}$ & $\begin{array}{r}-0.0059 \\
(0.0044)\end{array}$ & $\begin{array}{r}0.0058 \\
(0.0120)\end{array}$ & $\begin{array}{r}-0.0060 \dagger \\
(0.0032)\end{array}$ & $\begin{array}{l}-0.0085 \dagger \\
(0.0050)\end{array}$ & $\begin{array}{r}-0.0036 \\
(0.0040)\end{array}$ \\
\hline Lagged dependent & $\begin{array}{r}0.3876^{* *} \\
(0.1252)\end{array}$ & $\begin{array}{r}0.3884^{* *} \\
(0.1461)\end{array}$ & $\begin{array}{r}0.1274 \\
(0.2058)\end{array}$ & $\begin{array}{c}0.3338^{*} \\
(0.1379)\end{array}$ & $\begin{array}{r}0.2794 \\
(0.1774)\end{array}$ & $\begin{array}{r}0.1015 \\
(0.1550)\end{array}$ \\
\hline Average age & $\begin{array}{r}0.0817^{* *} \\
(0.0207)\end{array}$ & $\begin{array}{r}0.0895 * * \\
(0.0261)\end{array}$ & $\begin{array}{r}0.0228 \\
(0.0249)\end{array}$ & $\begin{array}{r}0.0736^{* *} \\
(0.0228)\end{array}$ & $\begin{array}{r}0.0811^{* *} \\
(0.0288)\end{array}$ & $\begin{array}{r}0.0191 \\
(0.0262)\end{array}$ \\
\hline Share of girls & $\begin{array}{r}-0.0968 \\
(0.0611)\end{array}$ & $\begin{array}{c}-0.1625^{*} \\
(0.0828)\end{array}$ & $\begin{array}{r}0.0182 \\
(0.0871)\end{array}$ & $\begin{array}{r}-0.1025 \\
(0.0629)\end{array}$ & $\begin{array}{c}-0.1544 \dagger \\
(0.0819)\end{array}$ & $\begin{array}{r}0.0077 \\
(0.0953)\end{array}$ \\
\hline Share hh-heads w/o ed. & $\begin{array}{c}0.1030^{*} \\
(0.0484)\end{array}$ & $\begin{array}{r}0.0879 \\
(0.0563)\end{array}$ & $\begin{array}{r}0.0863 \\
(0.0729)\end{array}$ & $\begin{array}{c}0.1112^{*} \\
(0.0483)\end{array}$ & $\begin{array}{r}0.0896 \\
(0.0563)\end{array}$ & $\begin{array}{r}0.0869 \\
(0.0814)\end{array}$ \\
\hline Adult literacy & $\begin{array}{r}-0.5251^{* *} \\
(0.1482)\end{array}$ & $\begin{array}{r}-0.5621^{* *} \\
(0.1712)\end{array}$ & $\begin{array}{r}-0.1906 \\
(0.2233)\end{array}$ & $\begin{array}{c}-0.4095^{*} \\
(0.1624)\end{array}$ & $\begin{array}{c}-0.4322^{*} \\
(0.1819)\end{array}$ & $\begin{array}{r}-0.1963 \\
(0.2289)\end{array}$ \\
\hline Rural share & $\begin{array}{c}0.0686^{*} \\
(0.0310)\end{array}$ & $\begin{array}{c}0.0841^{*} \\
(0.0381)\end{array}$ & $\begin{array}{r}-0.0263 \\
(0.0402)\end{array}$ & $\begin{array}{r}0.0645 \dagger \\
(0.0332)\end{array}$ & $\begin{array}{r}0.0713 \dagger \\
(0.0394)\end{array}$ & $\begin{array}{r}-0.0192 \\
(0.0375)\end{array}$ \\
\hline Region $\times$ year interactions & Yes & Yes & Yes & Yes & Yes & Yes \\
\hline Observations & 522 & 418 & 104 & 488 & 384 & 104 \\
\hline Nr. districts & 261 & 209 & 52 & 244 & 192 & 52 \\
\hline Hansen p-value & 0.332 & 0.159 & $0.050 \dagger$ & 0.269 & 0.162 & $0.090 \dagger$ \\
\hline
\end{tabular}




\section{B Figures}

Figure 1: Tariff reductions in Indonesia
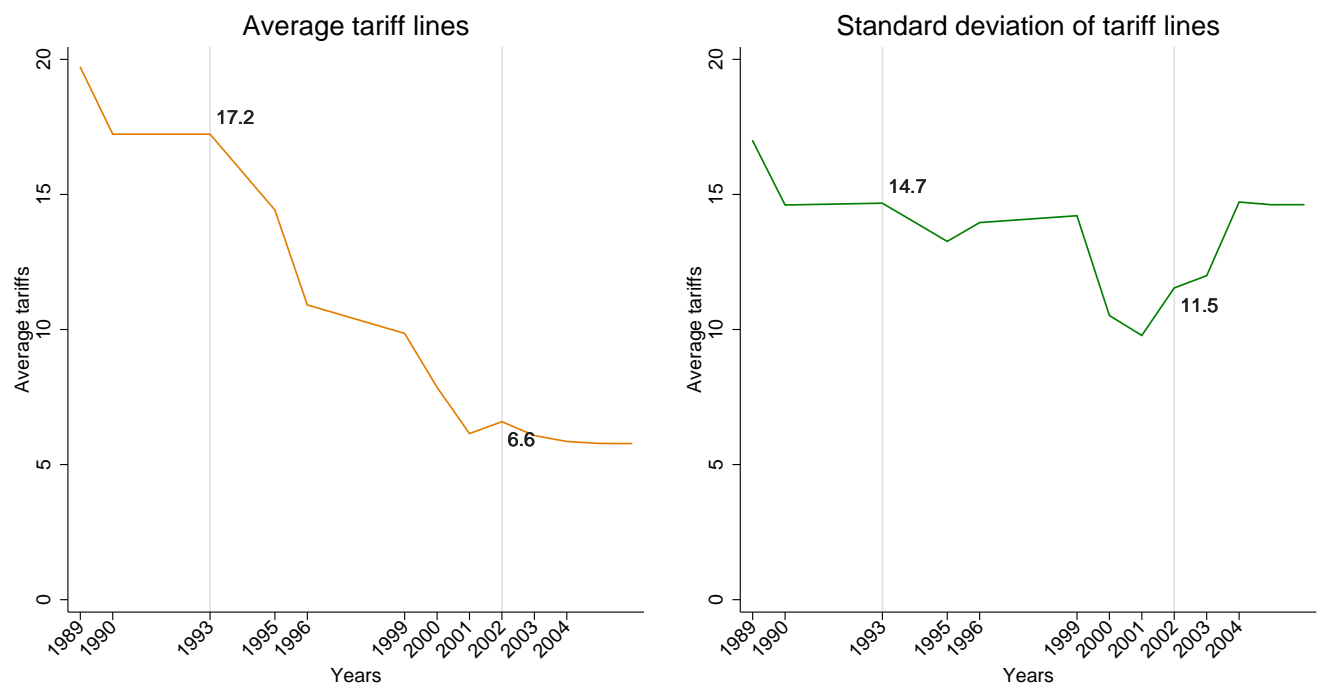

Figure 2: Tariff reductions by sectors
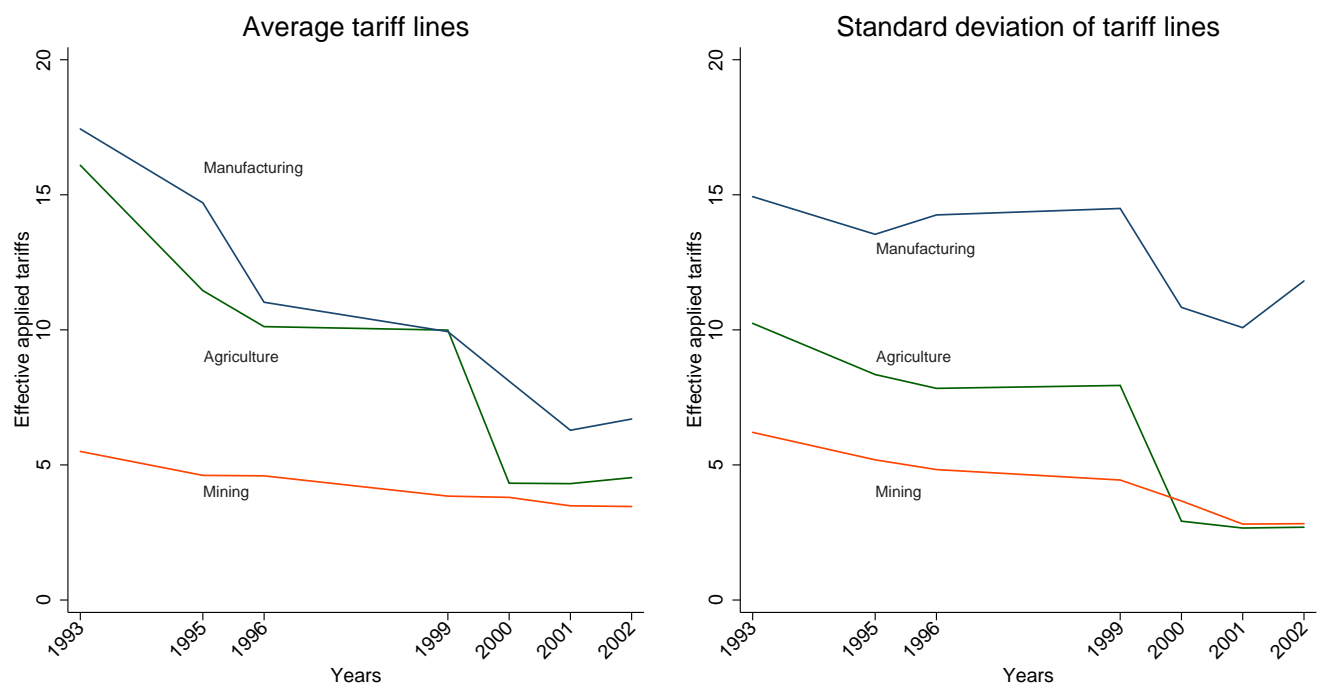
Figure 3: Tariff levels and reductions
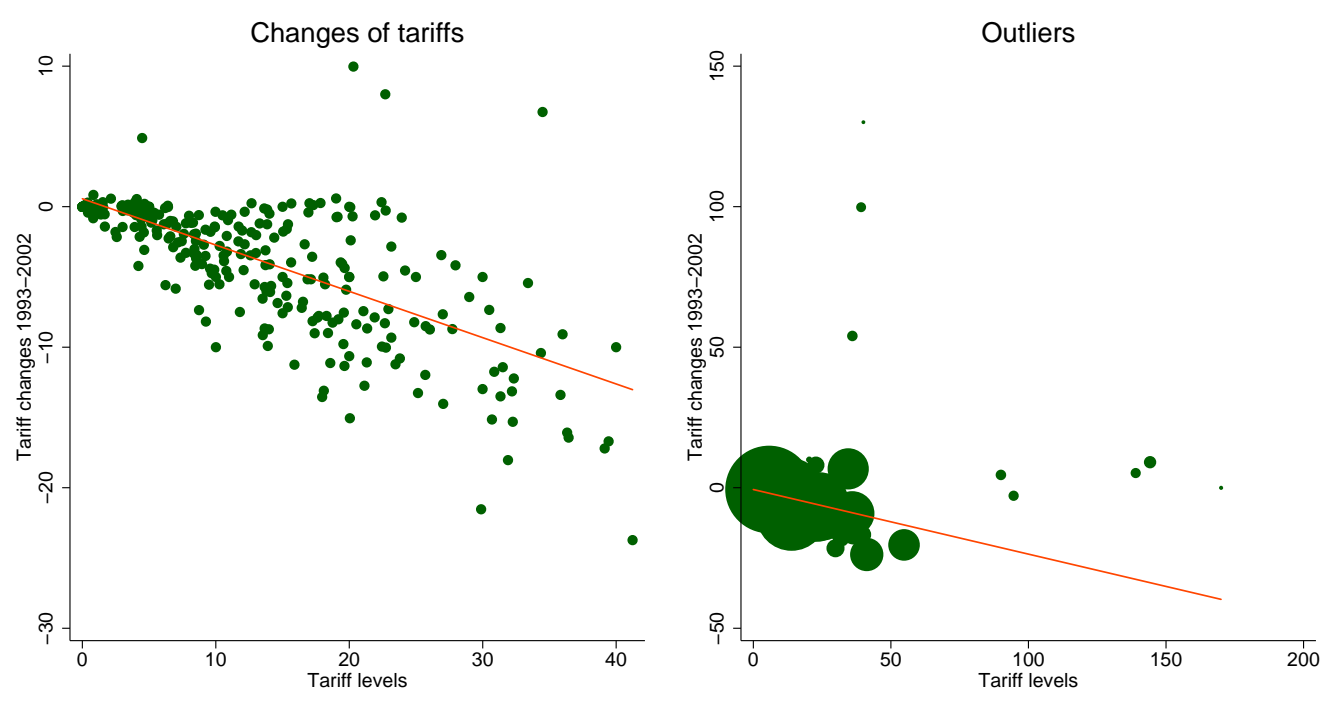

Figure 4: Work of children, by gender and age group
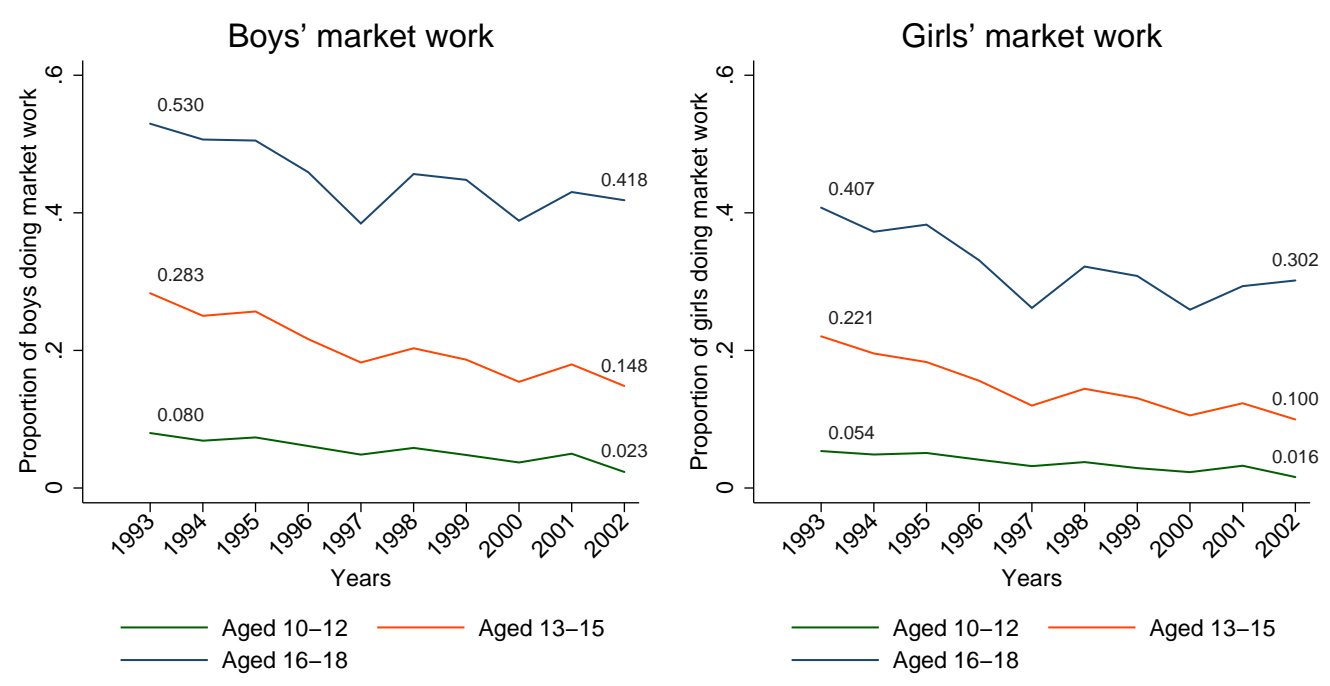


\section{Figure 5: Sectoral distribution of child work}
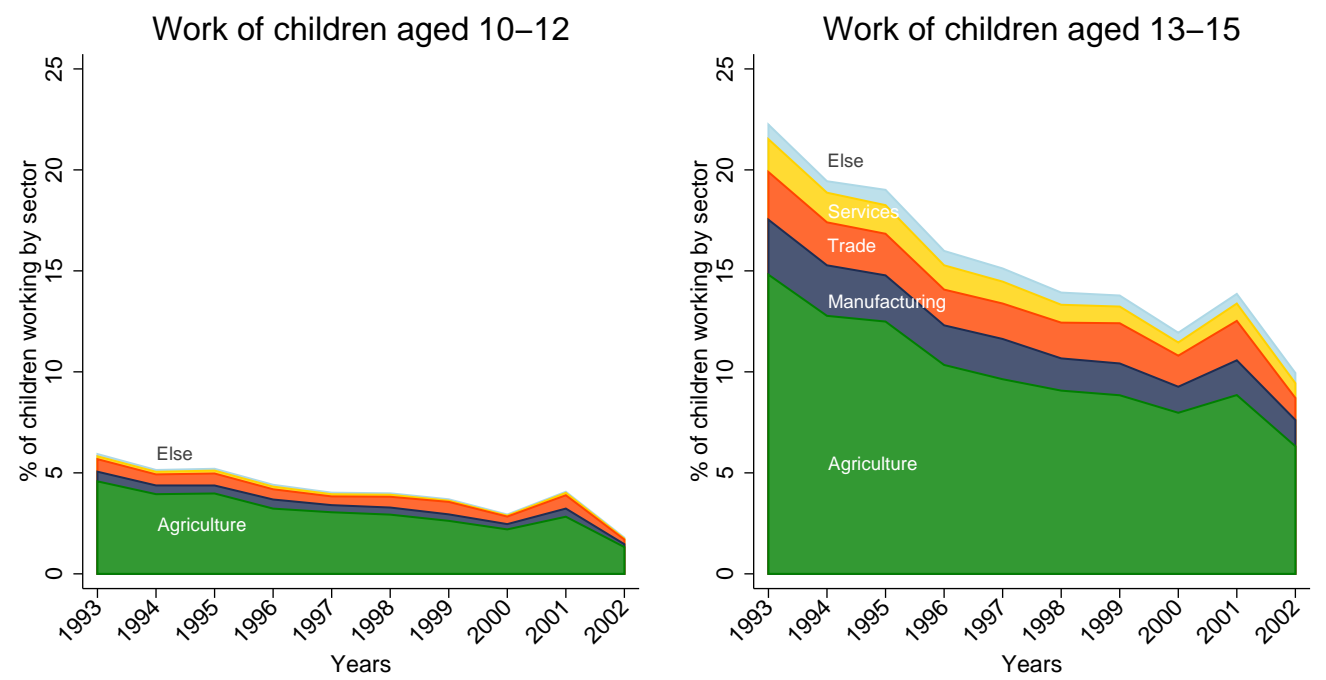

Figure 6: Evolution of tariff protection
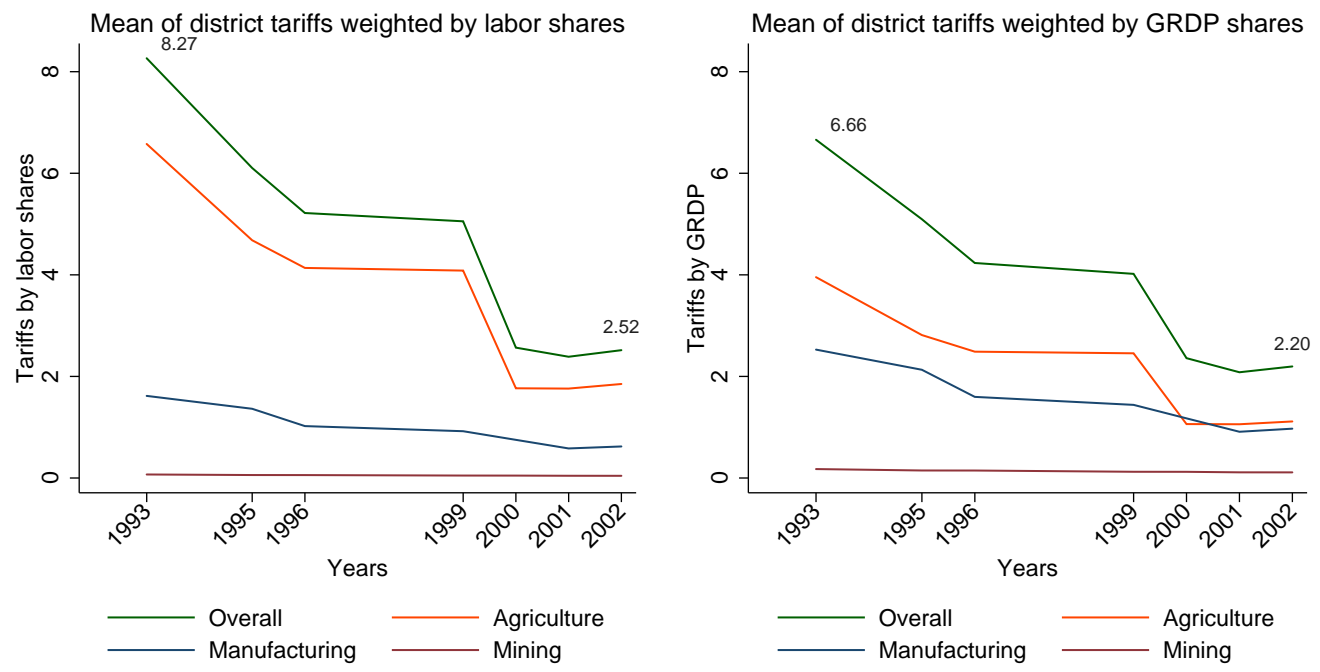
Figure 7: Initial district conditions and change in child work 1993-2002
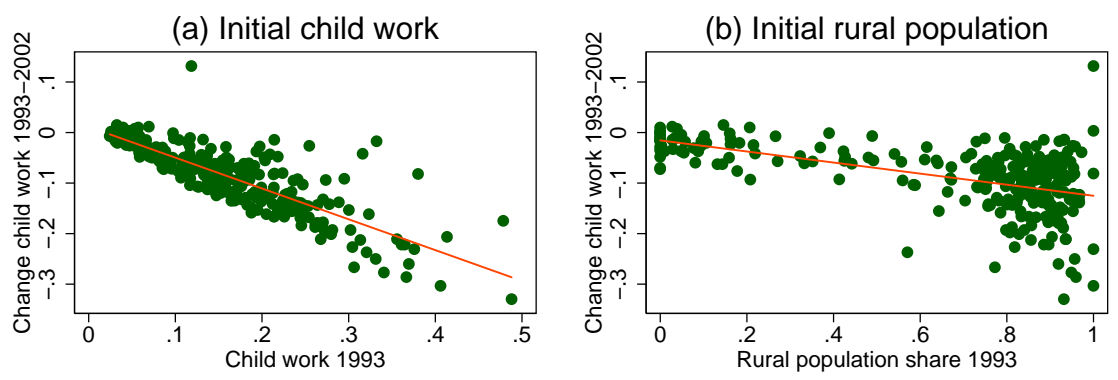

(c) Initial labour force agriculture
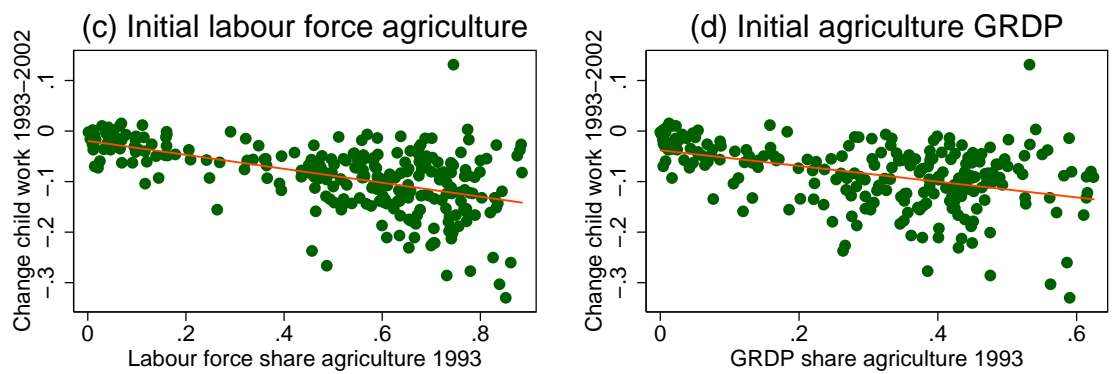